\title{
Dopuszczalność dowodów - wniosek Rzecznika Praw Obywatelskich (sygn. akt K 27/16) dotyczący ustawy - Kodeks postępowania karnego ${ }^{1}$
}

Admissibility of evidence - request of the Ombudsman (K 27/16) regarding the Act Code of Criminal Procedure: The object of the Constitutional Tribunal's review is Article 168a of the Code indicating the reasons of inadmissibility of evidence. The draft Sejm's position contains a conclusion that the above provision is consistent with the Constitution of the Republic of Poland. The applicant (the Commissioner for Citizens' Rights) claims that the challenged provision expresses an absolute obligation to include any evidence in the Polish criminal trial, regardless of how it was collected, including evidence obtained in violation of the prohibitions on collecting evidence. In the justification of the Sejm's draft position it was stated that the purpose of the amendment was to ensure that the offender would be held criminally responsible and that any innocent person would be released from this liability in any situation where material evidence could be subject to exclusion only due to a defect in the procedure for obtaining it.

\footnotetext{
Keywords: Code of Criminal Procedure | Constitutional Tribunal |"fruit of the poisonous tree" | material truth

Słowa kluczowe: Kodeks postępowania karnego | Trybunał Konstytucyjny |„owoce zatrutego drzewa"| prawda materialna
}

Doktor nauk prawnych, Uniwersytet Kardynała Stefana Wyszyńskiego w Warszawie, ekspert ds. legislacji BAS; a.poglodek@uksw.edu.pl.

\section{Trybunał Konstytucyjny}

Na podstawie art. 69 ust. 2 w związku z art. 42 pkt 3 ustawy z dnia 30 listopada 2016 r. o organizacji i trybie postępowania przed Trybunałem Konstytucyjnym (Dz. U. poz. 2072), w imieniu Sejmu Rzeczypospolitej Polskiej przedkładam wyjaśnienia w sprawie wniosku Rzecznika Praw Obywatelskich z 6 maja

1 Sprawa dotyczaca wniosku Rzecznika Praw Obywatelskich z dnia 6 maja 2016 r. (K 27/16), dotyczacego ustawy - Kodeks postępowania karnego sporządzona 23 lutego 2018 r.; BAS-WPTK 1037/16. 
2016 r. (sygn. akt K 27/16), jednocześnie wnosząc o stwierdzenie, że art. 168a ustawy z dnia 6 czerwca 1997 r. - Kodeks postępowania karnego (tj. Dz. U. 2017, poz. 1904) jest zgodny $\mathrm{z}$ art. 45 ust. $1 \mathrm{w}$ związku $\mathrm{z}$ art. 51 ust. $4 \mathrm{w}$ związku $\mathrm{z}$ art. 31 ust. 3 Konstytucji w związku z art. 6 Konwencji o ochronie praw człowieka i podstawowych wolności sporządzonej w Rzymie dnia 4 listopada $1950 \mathrm{r}$. (Dz. U. 1993, Nr 61, poz. 284, ze zm.), a także z art. 2, art. 7 i art. 47 Konstytucji, oraz nie jest niezgody $z$ art. 40 Konstytucji w związku z art. 3 Konwencji o ochronie praw człowieka i podstawowych wolności sporządzonej w Rzymie dnia 4 listopada 1950 r. (Dz. U. 1993, Nr 61, poz. 284, ze zm.).

Ponadto wnoszę o umorzenie postępowania w pozostałym zakresie na podstawie art. 59 ust. 1 pkt 2 ustawy o organizacji i trybie postępowania przed Trybunałem Konstytucyjnym ze względu na niedopuszczalność wydania orzeczenia.

\section{Uzasadnienie}

\section{Przedmiot kontroli}

Do Kancelarii Sejmu wpłynęło zawiadomienie Prezesa Trybunału Konstytucyjnego o wszczęciu postępowania przed Trybunałem Konstytucyjnym w sprawie z wniosku Rzecznika Praw Obywatelskich z dnia 6 maja 2016 r., sygn. akt K 27/16.

Przedmiotem kontroli jest art. 168a ustawy z dnia 6 czerwca 1997 r. - Kodeks postępowania karnego (tj. Dz. U. 2017, poz. 1904; dalej: k.p.k.): „Dowodu nie można uznać za niedopuszczalny wyłącznie na tej podstawie, że został uzyskany z naruszeniem przepisów postępowania lub za pomocą czynu zabronionego, o którym mowa w art. $1 \$ 1$ Kodeksu karnego, chyba że dowód został uzyskany w związku z pełnieniem przez funkcjonariusza publicznego obowiązków służbowych, w wyniku: zabójstwa, umyślnego spowodowania uszczerbku na zdrowiu lub pozbawienia wolności”.

Zaskarżony przepis w obecnym brzmieniu został wprowadzony do Kodeksu postępowania karnego ustawą z dnia 11 marca 2016 r. o zmianie ustawy - Kodeks postępowania karnego oraz niektórych innych ustaw (Dz. U. poz. 437; dalej: ustawa nowelizująca). Projekt tej ustawy wpłynął do Sejmu z propozycją usunięcia art. 168a k.p.k. w brzmieniu nadanym mu ustawą z dnia 27 września 2013 r., która weszła w życie z dniem 1 lipca 2015 r., a ustanowiła następującą treść tego przepisu: „Niedopuszczalne jest przeprowadzenie i wykorzystanie dowodu uzyskanego do celów postępowania karnego za pomocą czynu zabronionego, o którym mowa w art. $1 \$ 1$ Kodeksu karnego".

Pierwotnie projekt ustawy wniesiony przez rząd do Sejmu w dniu 27 stycznia 2016 r. (druk sejmowy nr 207/VIII kad.), ograniczał się do uchylenia art. 168a k.p.k. W uzasadnieniu do ustawy nowelizującej wskazano: „W ocenie projektodawcy zbędna jest regulacja art. 168a k.p.k., gdyż przepis ten wprowadza bardzo szeroki zakres zakazu dowodowego, niezależnie od okoliczności jego uzyskania. 
W tym stanie rzeczy celowe jest ocenianie każdej sytuacji in casu, z uwzględnieniem wszystkich aspektów sprawy, w oparciu o ogólnie przyjęte zasady w dorobku orzecznictwa i doktryny w perspektywie ostatnich kilkudziesięciu lat. Jak wskazuje się w doktrynie, «przepis art. 168a k.p.k., dyskwalifikujący dowody uzyskane za pomocą czynu zabronionego, znacznie rozszerza i tak szeroki obecnie system zakazów dowodowych w postępowaniu karnym. Dyskwalifikacja dowodów ocenianych nie tyle według kryteriów prawnoprocesowych wyznaczanych przez zakazy dowodowe, ile według kryteriów prawnokarnomaterialnych dotyczących przestępnych (a nawet jedynie zabronionych przez prawo karne) działań zarówno uczestników postępowania, jak i osób nieuczestniczących w procesie, może prowadzić do rezultatów chyba niezamierzonych przez ustawodawcę.

Z orzecznictwa Europejskiego Trybunału Praw Człowieka nie wynika również zakaz korzystania $\mathrm{z}$ dowodów pośrednio nielegalnych, pomimo dostrzeżenia nielegalnego źródła ich pochodzenia. [...]»" (uzasadnienie rządowego projektu ustawy o zmianie ustawy - Kodeks postępowania karnego oraz niektórych innych ustaw, druk sejmowy nr 207/VIII kad.).

Zmiana dalej idąca została wprowadzona $\mathrm{w}$ formie poprawki na etapie prac sejmowych. Dodano wówczas do ustawy nowelizującej art. 168a k.p.k. w obecnym brzmieniu podczas posiedzenia Komisji nadzwyczajnej do spraw zmian w kodyfikacjach. Przedstawiciele Ministerstwa Sprawiedliwości stwierdzili, że nowa regulacja jest przejawem samoograniczenia się ustawodawcy, który wprowadza przepis bardziej ograniczający w kwestii postępowania dowodowego, niż miało to miejsce przed 1 lipca $2015 \mathrm{r}$. Jednocześnie doprecyzowuje zakres stosowania przepisu, bowiem brzmienie art. 168a przed wykreśleniem w 2015 r. nie wyznaczało ani zakresu przedmiotowego czynów, ani zakresu podmiotowego osób popełniających czyny zabronione przez prawo karne. Wskazano, że nie sposób przyjąć, aby przepis art. 168a k.p.k. w obecnym brzmieniu zachęcał organy państwa, by za wszelką cenę zdobywały dowody niezbędne do dowiedzenia winy oskarżonego. Podkreślono, że celem wprowadzenia przepisu jest uniknięcie wątpliwości dotyczących sytuacji, w której z uwagi na nieznaczne uchybienia proceduralne byłyby eliminowane $z$ procesu dowody o fundamentalnym znaczeniu dla stwierdzenia winy bądź niewinności oskarżonego, podając jako przykład przeszukanie, $\mathrm{w}$ rezultacie którego ujawniono dowody popełnienia przestępstwa nieobjęte zakresem postanowienia o przeszukaniu. Projektodawca podkreślił, że nie do zaakceptowania jest sytuacja, w której ujawnienie dowodu zabójstwa $\mathrm{w}$ toku dokonywania przestępstwa, np. kradzieży $\mathrm{z}$ włamaniem, mogłoby skutkować uznaniem takiego dowodu przez sąd za niedopuszczalny. Zauważono też, że niedopuszczalna jest również sytuacja, w której zdobycie w nielegalny sposób dowodu przesądzającego o niewinności oskarżonego, powodowałoby konieczność uznania takiego dowodu za niedopuszczalny, a na taką wykładnię art. 168a k.p.k. w poprzednim brzmieniu pozwalała treść tego przepisu. Projektodawca wskazał też, że przecinek pomiędzy sformułowaniami „obowiązków służbowych” 
i „W wyniku” w obecnym brzmieniu art. 168a k.p.k. jest elementem koniunkcji między obiema frazami, tj. musi zaistnieć związek pomiędzy pełnieniem przez funkcjonariusza publicznego obowiązków służbowych i zabójstwem, spowodowaniem uszczerbku na zdrowiu lub pozbawieniem wolności, aby aktualizował się zakaz dowodowy, przewidziany w art. 168a k.p.k. in fine (stenogram z posiedzenia Komisji nadzwyczajnej do spraw zmian w kodyfikacjach z dnia 25 lutego 2016 r., http://orka.sejm.gov.pl/Zapisy8.nsf/wgskrnr/NKK-9).

Jak można wywodzić z treści wniosku Rzecznika Praw Obywatelskich (dalej: Rzecznik), przyjął on, że art. 168a k.p.k. wyraża bezwzględny nakaz uwzględnienia w polskim procesie karnym każdego dowodu, niezależnie od sposobu jego uzyskania, w tym dowodów uzyskanych z naruszeniem zakazów dowodowych, m.in. art. $171 \S 7$ k.p.k. Rzecznik podnosi bowiem przykładowo, że art. 168a k.p.k. nakłada na sąd obowiązek uwzględnienia dowodu uzyskanego wskutek tortur lub okrutnego, nieludzkiego albo poniżającego traktowania. Takie rozumienie kwestionowanego przepisu nie może jednak zostać uznane za prawidłowe, uwzględniając poza wykładnią językową także wykładnię autentyczną, systemową i funkcjonalną.

Na podstawie przebiegu prac ustawodawczych można stwierdzić, że: „celem znowelizowania art. 168a k.p.k. było ograniczenie dowolności organów procesowych w zakresie uznawania dowodów za niedopuszczalne a priori, bez przeprowadzenia ich oceny stosownie do treści art. 4 i art. 7 k.p.k., oraz wskazanie wyjątków od zasady swobodnego dowodzenia poprzez precyzyjne ujęcie w treści komentowanego przepisu in fine bezwzględnych zakazów dowodowych mających zapewnić respektowanie standardu konwencyjnego, a także jednoznaczne odrzucenie przez ustawodawcę koncepcji „owoców zatrutego drzewa” jako sprzecznej z fundamentalnymi zasadami polskiej procedury karnej, w szczególności zasadą prawdy materialnej, oraz celami postępowania karnego, mającymi uzasadnienie w normach konstytucyjnych, w szczególności z koniecznością dążenia do takiego ukształtowania procedury karnej, aby sprawca przestępstwa został wykryty i pociągnięty do odpowiedzialności karnej, a osoba niewinna nie poniosła tej odpowiedzialności” (stanowisko Prokuratora Generalnego, s. 63). Ustawodawca odwołał się w ten sposób do: „tych orzeczeń sądowych w których odrzucono doktrynę „owoców zatrutego drzewa” (tak m.in. w orzeczeniach Sądu Apelacyjnego w Katowicach z dn. 27 maja 2004, sygn. II AKa 160/04, LEX nr 149706; Sądu Najwyższego z dn. 14 listopada 2006 r., sygn. V KK 52/06, LEX nr 202271; z dn. 22 lutego 2007 r., sygn. V KK 183/06, LEX nr 274709; z dn. 5 lutego 2008 r., sygn. SNO 2/08, LEX nr 432189; z dn. 3 grudnia 2008 r., sygn. V KK 195/08, LEX nr 482213; z dn. 25 marca 2010 r., sygn. I KZP 2/10, LEX nr 564518; Sądu Apelacyjnego w Lublinie z dn. 22 stycznia 2013 r., sygn. II AKa 301/12, LEX nr 1289474; Sądu Najwyższego z dn. 30 października 2013 r., sygn. II KK 139/13, LEX nr 1391587, oraz z dn. 2 lutego 2016 r., sygn. IV KK 346/15, LEX nr 1976252)” (ibidem). Artykuł 168a k.p.k.: „stanowi lex generalis i podlega 
ograniczeniu przez leges speciales, w szczególności inne zakazy dowodowe. Należy go rozumieć w ten sposób, że w obecnym stanie prawnym nie można uznać za niedopuszczalny dowodu z powodu uzyskania go bezpośrednio lub pośrednio z powodu jedynie jakiegokolwiek, choćby porządkowego, naruszenia przepisów postępowania lub za pomocą czynu zabronionego, każdy taki dowód musi natomiast podlegać swobodnej ocenie sądu, dokonanej na zasadach przewidzianych w art. 4 i art. 7 k.p.k., a więc w zgodzie z zasadami obiektywizmu oraz swobodnej oceny dowodów. Stwierdzenie, że dowód został pozyskany nie w drodze czynu zabronionego, o którym mowa w art. $1 \S 1$ k.k., ale w drodze czynu sprzecznego z prawem cywilnym lub stanowiącego wykroczenie, przestępstwo skarbowe bądź wykroczenie skarbowe, nie jest przesłanką wystarczającą do wyeliminowania go z procesu karnego. Dowód nie może zostać uznany za niedopuszczalny nie tylko wyłącznie na tej podstawie, że został uzyskany za pomocą przestępstwa, lecz także przy stwierdzeniu jedynie realizacji znamion danego typu czynu zabronionego, w oderwaniu od stopnia społecznej szkodliwości i winy. Jednakże, w żadnych okolicznościach nie może zostać uznany za dopuszczalny dowód, uzyskany bezpośrednio lub pośrednio $\mathrm{w}$ związku $\mathrm{z}$ pełnieniem przez funkcjonariusza publicznego obowiązków służbowych w wyniku zabójstwa, umyślnego spowodowania uszczerbku na zdrowiu lub pozbawienia wolności. Wydaje się, że, wprowadzając ten zakaz dowodowy, ustawodawca chciał sprostać wymaganiom konwencyjnym dotyczącym zakazu wykorzystywania dowodów uzyskanych wskutek tortur, szczegółowo precyzując zakres niedopuszczalnych dowodów nielegalnych, zarówno bezpośrednio, jak i pośrednio" (ibidem, s. 64). Stąd też na gruncie art. 168a k.p.k. za niedopuszczalny powinien zostać uznany dowód, który: „1) został bezpośrednio lub pośrednio uzyskany w wyniku czynu zabronionego realizującego znamiona zabójstwa, umyślnego spowodowania uszczerbku na zdrowiu lub pozbawienia wolności popełnionego przez funkcjonariusza publicznego w związku z pełnieniem obowiązków służbowych lub 2) został bezpośrednio uzyskany wskutek złamania istniejącego już w prawie procesowym zakazu dowodowego” (ibidem, s. 65). „Ustalić również należy istnienie związku funkcjonalnego pomiędzy pozyskaniem dowodu a działaniami podejmowanymi przez funkcjonariusza publicznego w związku z pełnieniem obowiązków. Niezbędne jest także ustalenie, że osoba pozyskująca dowód działała w intencji jego uzyskania przy wykorzystaniu jednej z metod określonych w art. 168a k.p.k. in fine" (ibidem).

\section{Zarzuty wnioskodawcy}

1. Rzecznik podnosi, że: „już przed 2013 r. w orzecznictwie wykształciła się koncepcja nawiązująca do teorii owoców zatrutego drzewa, wedle której niedopuszczalne jest przeprowadzenie przed sądem dowodu, który został zdobyty w sposób niezgodny z prawem. [...]. Wprowadzenie do Kodeksu postępowania karnego art. 168a w brzmieniu ustalonym w nowelizacji z dnia 27 września 2013 r. nie 
tylko potwierdzało linię orzeczniczą Sądu Najwyższego, ale też konweniowało z dopuszczonymi do procesu karnego dowodami prywatnymi" (wniosek Rzecznika, s. 5). W 2016 r. ustawą nowelizującą zmieniono brzmienie art. 168a k.p.k., nadając mu brzmienie w ocenie Rzecznika niezgodne z Konstytucją. Rzecznik wskazuje, że: „ustawodawca, nie tylko uchylając - jak planowano pierwotnie art. 168a k.p.k., ale zmieniając jego treść w taki sposób, aby zobligować sądy do uwzględniania dowodów, nawet - z nielicznymi wyjątkami - zdobytych nielegalnie, wyeksplikował swoje intencje. Niewątpliwie celem zmiany było zaprzeczenie koncepcji niedopuszczalności niektórych dowodów, wypracowanej przez Sąd Najwyższy dzięki odwołaniu się do metody wykładni prawa w zgodzie z Konstytucją RP. Ustawodawca - twierdząc, że tego wymaga zasada prawdy materialnej - miał na celu możliwie daleko idące ograniczenie dyskrecjonalności sądu w ustalaniu możliwości dopuszczenia danego dowodu” (ibidem).

Rzecznik podkreśla, że: „konstruowanie implikacji między prawdą materialną i nakazem przeprowadzania wszystkich dowodów jest błędne. Organy państwa, w tym zwłaszcza prokuratura odpowiadająca za prowadzenie postępowania przygotowawczego i popieranie oskarżenia dysponują licznymi środkami umożliwiającymi pozyskiwanie materiału dowodowego w sposób legalny. Ograniczenie możliwości przeprowadzania dowodów zdobytych w sposób wypełniający znamiona czynu zabronionego nie uniemożliwia dotarcia do prawdy materialnej. Nie można także zapominać, że zasada prawdy materialnej jest bardzo ważną ale nie jedyną zasadą którą należy uwzględnić w ramach procesu karnego. Państwo nie powinno dążyć do prawdy «za wszelką cenę», nie zważając na naruszanie podstawowych praw i wolności człowieka. Najważniejszą a także jedną z niewielu, szansą na ochronę dóbr człowieka - pokrzywdzonego, sprawcy, innych uczestników postępowania - jest zapewnienie właściwych standardów postępowania, dających jednostce szansę na uzyskanie pomocy państwa i gwarancję zaniechania naruszania jej praw. W przeciwnym razie organy państwa, $\mathrm{z}$ istoty wykazujące tendencje ku omnipotencji, będą mogły dowolnie ingerować w esencjalne dobra jednostki, nie dając jej szansy na skuteczną obronę" (ibidem, s. 6).

Dalej Rzecznik podnosi, że: „zobowiązanie sądu do uwzględnienia dowodu, który został pozyskany z naruszeniem przepisów postępowania lub za pomocą czynu zabronionego narusza prawo do sprawiedliwego rozpatrzenia sprawy. Nie zmienia tego wprowadzenie do przepisu wyjątków, które uniemożliwiają przeprowadzenia dowodu pozyskanego $\mathrm{w}$ związku z pełnieniem przez funkcjonariusza publicznego obowiązków służbowych, w wyniku: zabójstwa, umyślnego spowodowania uszczerbku na zdrowiu lub pozbawienia wolności” (ibidem, s. 8). Wciąż bowiem, w ocenie Rzecznika pozostawia się: „szeroką możliwość dowodzenia w oparciu o materiał zdobyty z naruszeniem postępowania lub za pomocą czynu zabronionego [...]” (ibidem). Następnie Rzecznik wywodzi, że: „naruszenia prawa do sprawiedliwego procesu nie sanuje także zasada swobodnej oceny 
dowodów. Sprawiedliwość procesu narusza już samo dopuszczenie dowodu pozyskanego nielegalnie i włączenie go do materiału będącego podstawą rozstrzygnięcia sprawy” (ibidem). Rzecznik dostrzega, że: „możliwa być może byłaby taka wykładnia prokonstytucyjna, która pozwalałaby jednak sądowi na nie uwzględnienie dowodu w ustaleniach faktycznych będących podstawą wyroku, po jego uprzednim dopuszczeniu, tylko $\mathrm{z}$ uwagi na sposób jego pozyskania. W materii tak ważnej, kiedy waży się sprawiedliwość procesu, nie należy jednak wprowadzać rozstrzygnięć normatywnych, które powodowałyby tak liczne wątpliwości interpretacyjne" (ibidem, s. 8-9).

2. Rzecznik wywodzi również, że art. 168 k.p.k. stanowi zakwestionowanie wyrażonej w art. 7 Konstytucji zasady praworządności pro futuro, z tego względu, że ustawodawca: „nie tylko zauważa, że organy władzy publicznej - skądinąd odpowiadające za praworządne postępowanie - mogą postępować w sposób niezgodny z prawem, ale z góry to akceptuje. Co więcej, nakazuje wymiarowi sprawiedliwości opieranie swojej działalności na niepraworządnym działaniu organów władzy publicznej i ich funkcjonariuszy" (ibidem, s. 11). Podkreśla także, że: „taki wymóg nałożony na sądy może nawet zachęcać organy państwa do pozyskania materiału dowodowego bez względu na ograniczenia prawne. W niektórych, skomplikowanych postępowaniach, może to okazać się łatwiejsze - biorąc pod uwagę nawet ryzyko odpowiedzialności karnej - niż pozyskiwanie dowodu w sposób legalny" (ibidem).

Naruszona jest także, w ocenie Rzecznika, zasada przewidywalności procesu karnego. Artykuł 168a k.p.k.: „dekonstruuje możliwość przewidywania sposobu działania organów władzy publicznej, ponieważ legitymizuje działania niezgodne z prawem, pozwalając na budowanie strategii procesowej prokuratury także w oparciu o tzw. owoce zatrutego drzewa. Ten stan rzeczy wydaje się niezgodny nie tylko $\mathrm{z}$ art. 45 , ale także $\mathrm{z}$ art. 42 ust. 2 Konstytucji RP statuującym prawo do obrony we wszystkich stadiach postępowania" (ibidem, s. 13).

Rzecznik podnosi, że skutkiem bezpośrednim art. 168a k.p.k. jest więc: „samo dopuszczenie do przeprowadzenia dowodów pozyskanych z naruszeniem przepisów postępowania lub za pomocą czynu zabronionego" (ibidem). Oprócz tego pośrednio przepis ten: „legitymizuje bezprawne działania organów władzy publicznej, niejako skłaniając nawet te podmioty do zdobywania materiału dowodowego z naruszeniem przepisów prawa" (ibidem, s. 14). Rzecznik wskazuje, że: „niewątpliwie bezprawne pozyskiwanie dowodów przez organy władzy publicznej może naruszać art. 47 Konstytucji RP” (ibidem). Jak dalej wywodzi Rzecznik: „jeżeli zatem można zrekonstruować zakaz uchwalania przepisów, które pozwalałyby na zarządzanie kontroli operacyjnej w sposób arbitralny, to tym bardziej naruszać standardy konstytucyjne i konwencyjne musi przepis, który pozwala na wykorzystywanie w postępowaniu karnym materiałów zdobytych nawet nie na podstawie przepisów arbitralnych, ale nielegalnie, a więc wbrew zasadom kierującym realizowaniem czynności operacyjno-rozpoznawczych. $\mathrm{W}$ tym kontek- 
ście należy także przywołać normy rekonstruowane w oparciu o art. 51 ust. 2 i 4 Konstytucji RP. Po pierwsze, władze publiczne nie mogą pozyskiwać, gromadzić i udostępniać innych informacji o obywatelach niż niezbędne w demokratycznym państwie prawnym. Po drugie, każdy ma prawo do żądania sprostowania oraz usunięcia informacji nieprawdziwych, niepełnych lub zebranych w sposób sprzeczny z ustawą. Konstytucja wskazuje zatem wprost, że dane zebrane w sposób sprzeczny z ustawą powinny być usunięte na żądanie osoby, której dotyczą. Tym samym, przepis, który nie tylko nie nakazuje usunięcia takich danych, ale przeciwnie - wymaga od sądu uwzględnienia ich w procesie orzekania, jest niewątpliwie niezgodny z art. 54 ust. 4 Konstytucji RP” (ibidem, s. 16-17). Rzecznik, odwołując się do zasady a minori ad maius, podnosi, że: „jeżeli ustawodawca zabrania przetwarzania danych zebranych niezgodnie z prawem, a także nakazuje ich usunięcie, to tym bardziej zabronione jest wykorzystywanie tych danych w procedurze karnej, która w swojej naturze może skutkować istotnymi konsekwencjami dla jednostki” (ibidem, s. 17-18).

3. W ocenie Rzecznika art. 168a k.p.k. budzi także poważne wątpliwości: „dotyczącego [jego - dopisek A.P.] celowości i proporcjonalności sensu stricto. Aparat państwa wyposażony jest $\mathrm{w}$ bardzo szerokie instrumentarium pozwalające mu na legalne pozyskiwanie dowodów, które mogą być później przedmiotem oceny w postępowaniu karnym. Trudno jest znaleźć uzasadnienie dla przepisu nakładającego na sąd nie tylko możliwość, ale aż obowiązek uwzględnienia dowodów pozyskanych nielegalnie” (ibidem, s. 19). Podnosi też, że: „nie trudno zauważyć także jego niezgodność z art. 40 Konstytucji RP w związku z art. 3 Konwencji o ochronie praw człowieka i podstawowych wolności. Nałożenie na sąd obowiązku uwzględnienia dowodu pozyskanego w sposób niezgodny z przepisami lub za pomocą czynu zabronionego daje organom prowadzącym postępowanie możliwość wnioskowania o włączenie do sprawy także tych dowodów, które zostały pozyskane w sposób wypełniający znamiona tortur lub okrutnego, nieludzkiego albo poniżającego traktowania” (ibidem). Taka możliwości: „nie tylko jest niezgodna ze standardem konstytucyjnym i konwencyjnym, ale narusza także absolutny zakaz tortur oraz okrutnego, poniżającego i nieludzkiego zachowania, rozpoznany jako norma o charakterze ius cogens" (ibidem, s. 20). Proces, w którym zostaną wykorzystane takie dowody: „staje się nierzetelny, a więc prowadzony jest $\mathrm{z}$ naruszeniem art. $6 \mathrm{EKPC}$, a więc narusza także standard wynikający z art. 45 Konstytucji RP” (ibidem, s. 21).

4. Ostatecznie pozwala to Rzecznikowi także na stwierdzenie, że art. 168 k.p.k.: „jest niezgodny również z art. 2 Konstytucji RP, w tym zwłaszcza z zasadą zaufania obywateli do państwa i stanowionego przez nie prawa. [...] Nie da się mówić o przewidywalności, obliczalności, a tym bardziej o lojalności państwa wobec adresatów norm prawnych w sytuacji, gdy nielegalne działania organów władzy publicznej mogą stać się podstawą podejmowania czynności działających na niekorzyść jednostki. [...]” (ibidem). 


\section{Analiza formalnoprawna}

1. Trybunał Konstytucyjny na każdym etapie postępowania jest obowiązany do badania, czy nie zachodzi ujemna przesłanka wydania wyroku, skutkująca obligatoryjnym umorzeniem postępowania (postanowienia TK z: 6 lipca 2004 r., sygn. akt SK 47/03; 14 listopada 2007 r., sygn. akt SK 52/06; 10 listopada 2009 r., sygn. akt SK 45/08; 14 grudnia 2011 r., sygn. akt SK 29/09; 28 lutego 2012 r., sygn. akt SK 32/10; 18 czerwca 2013 r., sygn. akt SK 1/12; 28 października 2015 r., sygn. akt P 6/13).

Wniosek Rzecznika został wniesiony w dniu 6 maja 2016 r., a więc przed wejściem w życie ustawy z dnia 30 listopada 2016 r. o organizacji i trybie postępowania przed Trybunałem Konstytucyjnym (dalej: u.o.t.p.TK). Zgodnie z art. 1 ustawy z dnia 13 grudnia 2016 r. - Przepisy wprowadzające ustawę o organizacji i trybie postępowania przed Trybunałem Konstytucyjnym oraz ustawę o statusie sędziów Trybunału Konstytucyjnego (Dz. U. poz. 2074; dalej: p.w.u.o.t.p.TK): „Ustawa z dnia 30 listopada 2016 r. o organizacji i trybie postępowania przed Trybunałem Konstytucyjnym (Dz. U. poz. 2072) wchodzi w życie po upływie 14 dni od dnia ogłoszenia niniejszej ustawy, z wyjątkiem: 1) art. 1-6, które wchodzą w życie z dniem następującym po dniu ogłoszenia niniejszej ustawy; 2) art. 1632, które wchodzą w życie z dniem 1 stycznia 2018 r.". Ogłoszenie przepisów wprowadzających ustawę o organizacji i trybie postępowania przed Trybunałem Konstytucyjnym miało miejsce w dniu 19 grudnia 2016 r. Zgodnie z art. 3 p.w.u.o.t.p.TK: „, [t]raci moc ustawa z dnia 22 lipca 2016 r. o Trybunale Konstytucyjnym (Dz. U. poz. 1157), z wyjątkiem art. 18 ust. 1, 4 i 5, które tracą moc obowiązującą z dniem 1 stycznia 2018 r.” Zgodnie z regulacją art. 9 p.w.u.o.t.p.TK: „1. Do postępowań przed Trybunałem Konstytucyjnym, zwanym dalej „Trybunałem", wszczętych i niezakończonych przed dniem wejścia w życie ustawy, o której mowa w art. 1, stosuje się przepisy tej ustawy. 2. Czynności procesowe dokonane w postępowaniach, o których mowa w ust. 1, pozostają w mocy”.

Do wniosku Rzecznika mają zatem zastosowanie przepisy ustawy o organizacji i trybie postępowania przed Trybunałem Konstytucyjnym, a w szczególności art. 46 oraz art. 47 . Zgodnie $\mathrm{z}$ art. 46 u.o.t.p.TK: „[p]ismami procesowymi są wnioski, pytania prawne i skargi konstytucyjne, a także inne wnioski i oświadczenia uczestników postępowania, wnoszone do Trybunału w toku postępowania poza rozprawą". Artykuł 47 u.o.t.p.TK stanowi: „1. Wniosek złożony przez podmiot, o którym mowa w art. 191 ust. 1 pkt 1-5 Konstytucji, zawiera: 1) oznaczenie podmiotu uprawnionego do złożenia wniosku; 2) podanie podstawy prawnej działania podmiotu uprawnionego do złożenia wniosku; 3) oznaczenie rodzaju pisma procesowego; 4) określenie kwestionowanego aktu normatywnego lub jego części; 5) wskazanie wzorca kontroli; 6) uzasadnienie. 2. Uzasadnienie, o którym mowa w ust. 1 pkt 6 , zawiera: 1) przywołanie treści kwestionowanego wnioskiem przepisu wraz z jego wykładnią; 2) przywołanie treści wzorców kontroli wraz z ich wykładnią; 3) określenie problemu konstytucyjnego i zarzutu niekonstytu- 
cyjności; 4) wskazanie argumentów lub dowodów na poparcie zarzutu niekonstytucyjności. [...]”. Należy ponadto przypomnieć, że Trybunał Konstytucyjny związany jest zarzutami sformułowanymi w piśmie procesowym (wniosku, pytaniu prawnym, skardze konstytucyjnej), pochodzącym od podmiotu uprawnionego do inicjowania postępowania. Niemniej zarzuty te mogą podlegać rozpatrzeniu tylko wtedy, jeżeli zostały należycie uzasadnione. Jak podkreślił Trybunał Konstytucyjny: „przesłanka odpowiedniego uzasadnienia zarzutów nie powinna być traktowana powierzchownie i instrumentalnie. Przytaczane w piśmie procesowym argumenty mogą być mniej lub bardziej przekonujące [...], lecz zawsze muszą być argumentami „nadającymi się” do rozpoznania przez Trybunał Konstytucyjny" (wyrok TK z 19 października 2010 r., sygn. akt P 10/10). Konieczność uzasadnienia zarzutu sformułowanego w piśmie inicjującym postępowanie przed Trybunałem Konstytucyjnym wynika z domniemania konstytucyjności norm prawnych oraz z zasady kontradyktoryjności. W związku z tym wniosek Rzecznika nie spełnia wymogów uzasadnienia wniosku przewidzianych w art. 47 ust. 2 pkt 1 i 2 u.o.t.p.TK, Rzecznik nie dokonał bowiem wykładni kwestionowanego przepisu ani wskazanych wzorców kontroli.

Jednak, mając na uwadze okoliczność, że wnioskodawca w dniu składania wniosku nie mógł wiedzieć o konieczności spełnienia warunków formalnych, przewidzianych w art. 47 ust. 1 i 2 u.o.t.p.TK, należy uznać, że powyższe uchybienia nie powinny spowodować umorzenia postępowania w całości.

2. Zgodnie $\mathrm{z}$ wypowiedziami Trybunału Konstytucyjnego: „kontrola konstytucyjności ustaw przebiega w oparciu o domniemanie, że badane normy są zgodne z konstytucją. Ciężar dowodu spoczywa na podmiocie kwestionującym zgodność ustawy z konstytucją i dopóki nie powoła on konkretnych i przekonywających argumentów prawnych na rzecz swojej tezy, dopóty Trybunał Konstytucyjny uznawać będzie kontrolowane przepisy za konstytucyjne. W przeciwnym razie naruszeniu uległaby zasada kontradyktoryjności postępowania przed Trybunałem Konstytucyjnym, a Trybunał przekształciłby się w organ orzekający z inicjatywy własnej" (zob. orzeczenie TK z 24 lutego 1997 r., sygn. akt K 19/96, oraz orzeczenia TK z: 26 kwietnia 1995 r., sygn. akt K 11/94; 31 stycznia 1996 r., sygn. akt K 9/95; wyroki TK z: 27 czerwca 2008 r., sygn. akt K 51/07; 15 lipca 2009 r., sygn. akt K 64/07; 12 stycznia 2012 r., sygn. akt Kp 10/09). Jak wskazuje się w literaturze, wymóg uzasadnienia powołanych zarzutów oznacza konieczność przedstawienia argumentów, które przemawiają za stwierdzeniem niezgodności zaskarżonych norm prawnych z normami powołanymi jako podstawa kontroli. Wymóg ten odnosi się do każdego z podniesionych zarzutów niezgodności danej normy (zob. K. Wojtyczek, Ciężar dowodu i argumentacji w procedurze kontroli norm przez Trybunał Konstytucyjny, „Przegląd Sejmowy” 2004, nr 1, s. 17; L. Jamróz, Skarga konstytucyjna. Wstępne rozpoznanie, Białystok 2011, s. 191).

3. Jak wskazuje Trybunał: „przesłanka odpowiedniego uzasadnienia zarzutów w kontekście każdego wzorca kontroli nie powinna być traktowana powierz- 
chownie i instrumentalnie" (wyroki TK z: 19 października 2010 r., sygn. akt P 10/10; 23 października 2012 r., sygn. akt SK 11/12). Powyższe oznacza, że nie wystarczy sformułowanie samej tezy o niekonstytucyjności zaskarżonego przepisu. Uzasadnienie musi wskazywać precyzyjnie co najmniej jeden argument przemawiający za naruszeniem danego wzorca kontroli. Wymogu tego nie spełniają uwagi nazbyt ogólne, niejasne czy też czynione jedynie na marginesie innych rozważań (zob. np. wyrok TK z 5 czerwca 2014 r., sygn. akt K 35/11; postanowienie TK z 13 stycznia 2015 r., sygn. akt K 44/13). W opinii Trybunału: „wobec respektowania generalnej zasady, jaką jest domniemanie konstytucyjności aktu normatywnego, samo wskazanie w petitum wzorca kontroli, bez szczegółowego odniesienia się w uzasadnieniu do kwestionowanej regulacji prawnej lub lakoniczne sformułowanie zarzutu niekonstytucyjności nie może zostać uznane za „uzasadnienie postawionego zarzutu, z powołaniem dowodów na jego poparcie” w rozumieniu przepisów regulujących postępowanie przed Trybunałem Konstytucyjnym. W świetle utrwalonej praktyki orzeczniczej wymóg ten należy rozumieć jako nakaz odpowiedniego udowodnienia zarzutów stawianych w kontekście każdego wskazanego wzorca kontroli" (postanowienie TK z 21 stycznia 2015 r., sygn. akt K 13/13). W tym względzie należy wskazać, że Rzecznik wbrew wyrażonemu w orzecznictwie Trybunału Konstytucyjnego obowiązkowi rzetelnej i szczegółowej analizy zaskarżonego przepisu (postanowienie TK z 12 maja 2015 r., sygn. akt K 7/14) poprzestał jedynie na ustaleniu jego znaczenia zgodnie z dyrektywami wykładni językowej. Poważne wątpliwości budzi także spełnienie wymogów dotyczących uzasadnienia przedstawianych zarzutów. Przykładowo Rzecznik mimo wskazania jako wzorca kontroli art. 51 ust. 3 Konstytucji nie uzasadnił swojego stanowiska w tym zakresie - w uzasadnieniu wniosku nie umieszczono ani tej jednostki redakcyjnej wprost, ani żadnego zdania, które mogłoby się odnosić bezpośrednio do tego wzorca kontroli. Wobec jednak istotności problemu podniesionego przez Rzecznika w ocenie Sejmu wniosek powinien zostać rozpoznany merytorycznie.

\section{Analiza merytoryczna}

\section{- Wzorce kontroli}

1. Zgodnie z art. 42 ust. 2 Konstytucji: „Każdy, przeciw komu prowadzone jest postępowanie karne, ma prawo do obrony we wszystkich stadiach postępowania. Może on w szczególności wybrać obrońcę lub na zasadach określonych w ustawie korzystać z obrońcy z urzędu”. Przepis ten ustanawia konstytucyjną zasadę prawa do obrony (ius defensionis). W ujęciu konstytucyjnym prawo to oznacza: „możność podejmowania wszelkich działań niesprzecznych z prawem, które w przekonaniu osoby poddanej temu postępowaniu mogą potwierdzić jego wersje zdarzeń [...] oraz jego niewinności lub występowanie określonego rodzaju winy” (P. Sarnecki, Komentarz do art. 42 [w:] Konstytucja Rzeczypospolitej 
Polskiej. Komentarz, t. III, red. L. Garlicki, Warszawa 2003, s. 2). Konstytucyjne prawo do obrony należy rozumieć szeroko, jest ono bowiem nie tylko fundamentalną zasadą procesu karnego, ale też elementarnym standardem demokratycznego państwa prawnego (zob. wyrok TK z 3 listopada 2004 r., sygn. akt K 18/03). Istotą prawa do obrony jest: „podejmowanie działań zmierzających do odparcia stawianych oskarżonemu zarzutów za pomocą przyznanych mu uprawnień procesowych. Nie obejmują one zaś blokowania możliwości prowadzenia postępowania karnego wobec innych osób, także wtedy gdy to postępowanie związane jest przedmiotowo z postępowaniem karnym oskarżonego. Korzystanie z prawa do obrony nie może polegać na działaniach, które prowadzą do ochrony własnych interesów kosztem realizacji prawa do obrony innych współoskarżonych" (P. Karlik, T. Sroka, P. Wiliński, Komentarz do art. 42 [w:] Konstytucja RP. Komentarz, t. I, Art. 1-86, red. M. Safjan, L. Bosek, Warszawa 2016, nb. 186). Konstytucyjne prawo do obrony ma wymiar materialny i formalny (zob. wyroki TK z: 7 października 2008 r., sygn. akt P 30/07; 19 lutego 2008 r., sygn. akt P 48/06). Obrona materialna to możliwość bronienia przez oskarżonego jego interesów osobiście (np. możność odmowy składania wyjaśnień, prawo wglądu w akta i składania wniosków dowodowych). Obrona formalna to prawo do korzystania z pomocy obrońcy z wyboru lub z urzędu (zob. wyrok TK z 17 lutego 2004 r., sygn. akt SK 39/02). Prawo do obrony: „przysługuje od momentu rozpoczęcia postępowania do jego zakończenia). Tak szerokie ujęcie prawa do obrony wynika z podziału postępowania karnego i innych postępowań, których przedmiotem jest odpowiedzialność o zbliżonym charakterze (dyscyplinarna, karnoskarbowa, wykroczeniowa) na kilka stadiów. W ich ramach można wyróżnić tzw. postępowanie przygotowawcze (postępowanie wyjaśniające), postępowanie rozpoznawcze sądowe oraz postępowanie odwoławcze, co z kolei jest konsekwencją obowiązywania konstytucyjnej zasady prawa do sądu (art. 45 ust. 1 Konstytucji RP) oraz dwuinstancyjności postępowania sądowego (art. 176 ust. 1 Konstytucji RP). Nie ulega wątpliwości, że prawo do obrony musi przysługiwać jednostce w każdej z tych faz postępowania. Jednocześnie zakres uprawnień wchodzących w skład prawa do obrony może się różnić na poszczególnych etapach i być adekwatny do ich istoty" (P. Karlik, T. Sroka, P. Wiliński, Komentarz do art. 42, op. cit., nb. 225). Na prawo do obrony składa się wiele szczególnych praw, do których zaliczyć można:

- prawo do wyboru sposobu i środków obrony, zgodnie z orzecznictwem Trybunału Konstytucyjnego zawiera w sobie dwa zasadnicze elementy: „prawo wyboru sposobów obrony oraz prawo wyboru służących do ich realizacji środków” (zob. wyrok TK z 28 kwietnia 2009 r., sygn. akt P 22/07),

- prawo do znajomości stawianych zarzutów „obejmuje zarówno prawo do informacji o istocie zarzutów, jak i ich przyczynie, a także kwalifikacji prawnej stawianych zarzutów. Jest niezbędnym warunkiem skutecznego prowadzenia obrony w toku każdego postępowania o charakterze represyjnym. Prawo to 
ma na celu niedopuszczenie do oskarżenia i skazania osoby za czyn, który nie jest jej oficjalnie przedstawiony w formie zarzutu, ani też za czyn zakwalifikowany z surowszego przepisu niż było to wcześniej zakomunikowanie" (P. Karlik, T. Sroka, P. Wiliński, Konstytucja RP, Komentarz do art. 42, op. cit., nb. 212),

- prawo do odpowiedniego czasu i możliwości przygotowania obrony „zawiera w sobie dwa podstawowe elementy: prawo do dysponowania odpowiednim czasem do przygotowania obrony oraz prawo do możliwości jej przygotowania, tj. prawo do zapewnienia odpowiednich warunków przygotowania obrony. Prawo do zapewnienia odpowiedniego czasu do przygotowania obrony jednocześnie nakłada na ustawodawcę obowiązek adekwatnego wyznaczenia terminów dokonywania działań przez jednostkę" (P. Karlik, T. Sroka, P. Wiliński, Komentarz do art. 42, op. cit., nb. 213),

- prawo do obrony osobistej „przysługuje w każdym stadium postępowania, nie jest ono jednak nieograniczone" (zob. wyrok TK z 28 kwietnia 2009 r., sygn. akt P 22/07, „Prokuratura i Prawo” 2009, nr 68, poz. 585). Ustawodawca przewiduje sytuacje, w których ciężar obrony przejąć musi obrońca. Ograniczenie tego prawa związane jest z przekonaniem, iż istnieją sytuacje, w których jednostka nie jest w stanie skutecznie prowadzić osobiście swojej obrony bądź też wykonać określonych czynności procesowych. Jest więc ono paradoksalnie wyrazem dążenia do zapewnienia prawa do obrony tam, gdzie nie można w pełni świadomie bądź efektywnie z niego skorzystać” (P. Karlik, T. Sroka, P. Wiliński, Komentarz do art. 42, op. cit., nb. 214),

- prawo do posiadania i korzystania z pomocy obrońcy „mieści w sobie zarówno prawo do powołania obrońcy, jak i prawo do korzystania z jego pomocy, a więc działania obrońcy na rzecz oskarżonego (zob. wyroki TK z: 7 października 2008 r., sygn. akt P 30/07; 11 grudnia 2008 r., sygn. akt K 33/07)” (ibidem, nb. 215),

- prawo do swobody wypowiedzi, które obejmuje także: „prawo do składania wyjaśnień i ewentualnej odmowy ich składania. Dodatkowo z faktu skorzystania przez jednostkę z tzw. prawa do milczenia, nie można wyciągać negatywnych konsekwencji. Powyższe wynika $\mathrm{z}$ obowiązywania w polskim porządku prawnym zasady nemo se ipsum accusare tenetur" (ibidem, nb. 217),

- prawo dostępu do materiału dowodowego: „jest podstawowym warunkiem realnego udziału w toczącym się postępowaniu. Skuteczna obrona jest bowiem niemożliwa albo co najmniej niezwykle utrudniona, jeśli jednostka pozbawiona zostanie możliwości dostępu do zgromadzonego w sprawie materiału dowodowego. W procesie karnym prawo do dostępu do materiału dowodowego nie zostało ukształtowane jednolicie. Najpełniej uprawnienie to realizowane jest na etapie postępowania jurysdykcyjnego, gdzie strony mają niczym nieskrępowaną możliwość zapoznawania się z materiałami dowodowymi” (J. Skorupka, Udostępnienie akt sprawy podejrzanemu, „Proku- 
ratura i Prawo" 2007, nr 5, s. 65 i n.). Zupełnie inaczej ukształtowana jest kwestia dostępu do materiału dowodowego na etapie postępowania przygotowawczego. Wynika to oczywiście $\mathrm{z}$ samej istoty i charakteru tej fazy procesu karnego, gdzie z uwagi na dobro prowadzonego postępowania lub ważny interes państwa organ prowadzący śledztwo lub dochodzenie może odmówić udostępnienia materiału dowodowego. Obowiązująca tradycyjnie reguła ograniczonej jawności materiału dowodowego na etapie postępowania przygotowawczego doznała jednak bardzo istotnego ograniczenia. Zgodnie z - wielokrotnie nowelizowanym - art. $156 \$ 5$ a k.p.k. „nie można odmówić dostępu do materiału dowodowego, który stanowi podstawę wniosku o zastosowanie albo przedłużenie tymczasowego aresztowania. Wszelkie decyzje zapadłe w tym zakresie muszą być poczynione w oparciu o materiał dowodowy jawny dla oskarżonego (art. 249a KPK; zob. wyr. TK z: 3.6.2008 r., K 42/07, OTK-A 2008, Nr 5, poz. 77; 20.5.2014 r., SK 13/13, OTK-A 2014, Nr 5, poz. 54; P. Kardas, Standard rzetelnego procesu, s. 89)" (P. Karlik, T. Sroka, P. Wiliński, Komentarz do art. 42, op. cit., nb. 218). Prawo dostępu do materiału dowodowego „uznać można za uprawnienie do korzystania $\mathrm{z}$ tej samej wiedzy procesowej i tych samych materiałów procesowych (dowodów), jakie posiada organ prowadzący postępowanie" (ibidem, nb. 219),

- prawo do inicjatywy dowodowej: „to uprawnienie, zgodnie z którym strona może wystąpić do organu prowadzącego postępowanie z żądaniem przeprowadzenia wskazanego dowodu. Istota tego uprawnienia polega na możliwości wpływania na kierunek prowadzonego postępowania dowodowego, uzupełniania ustaleń organów procesowych" (ibidem, nb. 220),

- prawo do udziału w czynnościach dowodowych: „to uprawnienie, zgodnie z którym oskarżony ma zapewnioną możliwość uczestnictwa w przeprowadzaniu dowodów, w toku postępowania karnego. Prawo udziału w czynnościach dowodowych może być pojmowane jako element szerszego uprawnienia - do udziału w czynnościach procesowych, obejmujących: 1) udział w czynnościach dowodowych; 2) udział w posiedzeniach sądu; 3) udział w rozprawie" (ibidem, nb. 221).

„ «Naruszeniem prawa do obrony nazwać należy bezprawne utrudnienie lub pozbawienie oskarżonego wykonywania przysługujących mu uprawnień procesowych, służących ochronie jego interesów w postępowaniu karnym» (P. Wiliń$s k i$, Zasada prawa do obrony, s. 549). [...]. Na podstawie analizy zakresu prawa do obrony stwierdzić możemy, iż naruszenie prawa do obrony polegać może na: «1) niedopuszczalnym ograniczeniu uprawnień niepodlegających ograniczeniu; 2) nadmiernym ograniczeniu któregokolwiek z pozostałych uprawnień; 3) pozbawieniu oskarżonego jednego lub więcej uprawnień»” (ibidem, nb. 226).

Przyjmuje się, że zakres stosowania art. 42 Konstytucji obejmuje nie tylko odpowiedzialność karną sensu stricto, a więc za przestępstwa, ale również odpo- 
wiedzialność za wykroczenia (wyrok TK z 3 czerwca 2014 r., sygn. akt K 19/11), a także: „inne formy odpowiedzialności prawnej związane z wymierzaniem kar wobec jednostki” (zob. np. wyroki TK z: 8 lipca 2003 r., sygn. akt P 10/02; 26 listopada 2003 r., sygn. akt SK 22/02; 28 października 2015 r., sygn. akt SK 59/13). Do tych ostatnich Trybunał Konstytucyjny zaliczył m.in. postępowanie karnoskarbowe (wyrok TK z 9 lipca 2002 r., sygn. akt P 4/01) oraz postępowanie dyscyplinarne (wyrok TK z 28 listopada 2007 r., sygn. akt K 39/07).

2. Konstytucja w art. 45 ust. 1 przewiduje, że: „[k]ażdy ma prawo do sprawiedliwego i jawnego rozpatrzenia sprawy bez nieuzasadnionej zwłoki przez właściwy, niezależny, bezstronny i niezawisły sąd”. Zgodnie z art. 45 ust. 1 Konstytucji każdy ma prawo do sprawiedliwego i jawnego rozpatrzenia sprawy bez nieuzasadnionej zwłoki przez właściwy, niezależny, bezstronny i niezawisły sąd. Wobec czego istota prawa do sądu sprowadza się więc do zapewnienia ochrony sądowej w sprawach dotyczących sfery praw lub wolności danego podmiotu (postanowienie TK z 13 kwietnia 1999 r., sygn. akt Ts 24/99). Prawo do sądu wedle utrwalonego orzecznictwa Trybunału Konstytucyjnego obejmuje:

- „prawo dostępu do sądu, tj. prawo uruchomienia postępowania przed sądem - organem o określonej charakterystyce (właściwym, niezależnym, bezstronnym i niezawisłym);

- prawo do właściwej procedury przed sądem;

- prawo do wiążącego rozstrzygnięcia sprawy" (wyroki TK z: 9 czerwca 1998 r., sygn. akt K 28/97; 10 lipca 2000 r., sygn. akt SK 12/99; stanowisko to zostało wielokrotnie powtórzone w późniejszym orzecznictwie).

W 2007 r. Trybunał uzupełnił te elementy prawa do sądu o „prawo do odpowiedniego kształtowania ustroju i pozycji organów rozpoznających sprawy” (wyrok z 24 października 2007 r., sygn. akt SK 7/06). Stanowisko to pojawia się również w nowszej judykaturze, w której wyodrębnia się cztery elementy prawa do sądu (np. wyroki TK z: 13 stycznia 2015 r., sygn. akt SK 34/12; 30 września 2014 r., sygn. akt SK 22/13; 15 kwietnia 2014 r., sygn. akt SK 12/13; 6 listopada 2012 r., sygn. akt K 21/11). Trybunał podkreślił również, że: „W państwie prawnym prawo do sądu nie może być rozumiane jedynie formalnie, jako dostępność drogi sądowej w ogóle, lecz i materialnie, jako możliwość prawnie skutecznej ochrony praw na drodze sądowej [...]”. Podobne stanowisko zajął Sąd Najwyższy, według którego prawo do sądu nie wygasa w momencie złożenia powództwa i podjęcia na tej podstawie procesu, ale chodzi w nim o to, aby sąd rozpoznał sprawę co do jej istoty (postanowienie SN z 19 lipca 2006 r., sygn. akt I CSK 112/06). Ponadto TK zwraca uwagę na znaczenie prawa do wysłuchania, stwierdzając, że naruszenie prawa do sądu: „przejawia się w pozbawieniu [...] tzw. prawa do wysłuchania, które wprawdzie nie zostało wyrażone w Konstytucji, jednak jest powszechnie uznane za składową prawa do sądu” (wyrok TK z 12 marca 2002 r., sygn. akt P 9/01). Prawo do sądu istnieje nawet wówczas, gdy jakaś ustawa regulująca pra- 
wa i obowiązki jednostki nie przewiduje możliwości wystąpienia na drogę sądową (zob. wyrok SN z 7 kwietnia 1999 r., sygn. akt I PKN 648/98; uchwała SN z 18 stycznia 2001 r., sygn. akt III ZP 28/00).

Konstytucyjne prawo do sądu ma aspekt pozytywny, zawiera bowiem dyrektywy, zobowiązujące ustawodawcę do należytego ukształtowania systemu wymiaru sprawiedliwości w wymiarze instytucjonalnym i proceduralnym oraz zapewnienia jego efektywnego funkcjonowania. W tym aspekcie można mówić o obowiązku ustawodawcy ustanowienia regulacji prawnej, która zapewnia rozpatrzenie sprawy przez sąd, na żądanie zainteresowanego. Negatywny aspekt prawa do sądu wyraża się w zakazie zamykania lub nadmiernego ograniczania dostępu do wymiaru sprawiedliwości (art. 45 ust. 1 w związku z art. 77 ust. 2 Konstytucji). Fundamentalnym założeniem Konstytucji jest jej aksjologiczna i teleologiczna spójność, dlatego też dyrektywa zakazująca zamykania drogi sądowej musi być uwzględniania w procesie wykładni ogólnej zasady prawa do sądu (wyroki TK z: 9 czerwca 1998 r., sygn. akt K 28/97; 15 października 2001 r., sygn. akt K 12/01; 7 września 2004 r., sygn. akt P 4/04; 29 stycznia 2013 r., sygn. akt SK 28/11).

Trybunał Konstytucyjny w swoim orzecznictwie podkreślił, że z prawa do sądu wynika prawo do zastosowania sprawiedliwej procedury, tj. takiej, która: „powinna zapewniać stronom uprawnienia procesowe stosowne do przedmiotu prowadzonego postępowania. Wymóg sprawiedliwego postępowania zakłada bowiem dostosowanie jego zasad do specyfiki rozpoznawanych spraw" (wyrok TK z 16 listopada 2011 r., sygn. akt SK 45/09). Prawo do odpowiedniego ukształtowania postępowania ma charakter uniwersalny w tym sensie, że dotyczy każdego rodzaju postępowania sądowego, które objęte jest gwarancjami składającymi się na prawo do sądu (zob. wyrok TK z 12 lipca 2011 r., sygn. akt SK 49/08). Prawo to obowiązuje więc niezależnie od rodzaju załatwianej sprawy, jeżeli tylko ustawodawca powierza jej rozpoznanie sądowi przedmiotu sprawy (praw lub obowiązków, których dotyczy), sposobu jej wszczęcia (na żądanie zainteresowanego podmiotu, organu publicznego albo z urzędu) oraz etapu, na którym znajduje się rozstrzygana sprawa (zob. wyroki TK z: 12 stycznia 2010 r., sygn. akt SK 2/09; 11 maja 2011 r., sygn. akt SK 11/09; 12 lipca 2011 r., sygn. akt SK 49/08). Ustawodawca zwykły jest uprawniony do różnicowania postępowań sądowych w zależności od ich charakteru, przedmiotu rozpoznawanych w nich spraw, znaczenia dochodzonych w nich praw, i obowiązków dla zainteresowanych podmiotów, celów realizowanych w ramach tych postępowań, zakresu kognicji sądu, a także etapu, na którym znajduje się rozstrzygana sprawa (zob. wyroki TK z: 13 stycznia 2004 r., sygn. akt SK 10/03; 28 lipca 2004 r., sygn. akt P 2/04; 26 stycznia 2005 r., sygn. akt P 10/04; 16 listopada 2011 r., sygn. akt SK 45/09; zob. też wyroki TK z: 28 lipca 2004 r., sygn. akt P 2/04; 26 stycznia 2005 r., sygn. akt P 10/04; 20 października 2010 r., sygn. akt P 37/09; 16 listopada 2011 r., sygn. akt SK 45/09). Ocena konstytucyjności tych szczegółowych rozwiązań i wyłaniającego się z nich kształtu określonego rodzaju postępowania sądowego wymaga odniesienia tego 
kształtu do wymagań konstytucyjnych w ujęciu całościowym (zob. wyroki TK z: 28 lipca 2004 r., sygn. akt P 2/04; 26 stycznia 2005 r., sygn. akt P 10/04; 20 października 2010 r., sygn. akt P 37/09; 16 listopada 2011 r., sygn. akt SK 45/09). Takie prawo ustawodawcy nie oznacza arbitralności w stanowieniu przepisów proceduralnych, przykładowo takich, które ponad miarę, a więc bez wystąpienia istotnych racji, ograniczają prawa procesowe strony (zob. wyroki TK z: 20 października 2010 r., sygn. akt P 37/09; 16 listopada 2011 r., sygn. akt SK 45/09). Wymagane jest choćby zapewnienie sprawiedliwości proceduralnej, która, jak wskazuje TK, stanowi gwarancję tego, aby prawo do sądu nie było prawem fasadowym (zob. wyroki TK z: 26 lutego 2008 r., sygn. akt SK 89/06; 29 kwietnia 2008 r., sygn. akt SK 11/07; 20 października 2010 r., sygn. akt P 37/09).

Wreszcie konstytucyjny nakaz sprawiedliwego rozpatrzenia sprawy zawiera w sobie trzy podstawowe gwarancje (zob. wyroki TK z: 31 marca 2005 r., sygn. akt SK 26/02; 16 stycznia 2006 r., sygn. akt SK 30/05; 2 października 2006 r., sygn. akt SK 34/06; 20 listopada 2007 r., sygn. akt SK 57/05; 26 lutego 2008 r., sygn. akt SK 89/06; 12 stycznia 2010 r., sygn. akt SK 2/09; 18 października 2011 r., sygn. akt SK 39/09; 8 kwietnia 2014 r., sygn. akt SK 22/11):

- możność bycia wysłuchanym (prawo do wysłuchania),

- ujawnienie w czytelny sposób motywów rozstrzygnięcia (prawo do uzasadnienia lub szerzej - prawo do informowania),

- zapewnienie przewidywalności postępowania (prawo do przewidywalności postępowania; we wcześniejszym orzecznictwie wskazywano także na prawo do przewidywalności rozstrzygnięcia - zob. wyrok TK z 17 października 2000 r., sygn. akt SK 5/99).

3. Zgodnie $\mathrm{z}$ art. 47 Konstytucji: ,[k]ażdy ma prawo do ochrony prawnej życia prywatnego, rodzinnego, czci i dobrego imienia oraz do decydowania o swoim życiu osobistym". Przepis ten, po pierwsze, wyraża prawo jednostki do ochrony prawnej życia prywatnego, rodzinnego, czci, dobrego imienia i wiąże się ze stosownymi pozytywnymi obowiązkami władzy państwowej. Po drugie, w zakresie prawa do decydowania o swoim życiu osobistym, ma w istocie charakter „wolności” i polega "na wykluczeniu wszelkiej postronnej ingerencji w sferę życia osobistego jednostki" (P. Sarnecki, Komentarz do art. 47 [w:] Konstytucja Rzeczypospolitej Polskiej. Komentarz, t. III, red. L. Garlicki, Warszawa 2003, s. 1; zob. również wyroki TK z: 2 kwietnia 2001 r., sygn. akt SK 10/00; 9 lipca 2009 r., sygn. akt SK 48/05).

Jak wskazuje Trybunał Konstytucyjny: „[k]oncepcja prawa do prywatności zaczęła stosunkowo niedawno odgrywać poważniejszą rolę w regulacjach konstytucyjnych i orzecznictwie sądowym. Zdołała już jednak zyskać sobie trwałe miejsce we współczesnych państwach demokratycznych. Stanowią ją zasady i reguły odnoszące się do różnych sfer życia jednostki, a ich wspólnym mianownikiem jest przyznanie jednostce prawa „do życia własnym życiem układanym 
według własnej woli z ograniczeniem do niezbędnego minimum wszelkiej ingerencji zewnętrznej” (A. Kopff, Koncepcje prawa do intymności i do prywatności życia. Zagadnienia konstrukcyjne, „Studia Cywilistyczne” 1972, t. XX). Tak rozumiana prywatność odnosi się przede wszystkim do życia osobistego, rodzinnego, towarzyskiego i czasem jest określana jako „prawo do pozostawienia w spokoju” (zob. W. Sokolewicz, Prawo do prywatności [w:] Prawa człowieka w Stanach Zjednoczonych, Warszawa 1985, s. 252). Na ogół przyjmuje się, że prywatność odnosi się też do ochrony informacji dotyczących danej osoby i gwarantuje m.in. pewien stan niezależności, w ramach którego jednostka może decydować o zakresie i zasięgu udostępniania i komunikowania innym osobom informacji o swoim życiu” (orzeczenie TK z 24 czerwca 1997 r., sygn. akt K 21/96).

Prawo do prywatności nie ma charakteru absolutnego i jako takie może być limitowane. Podlega to jednak ocenie przez pryzmat art. 31 ust. 3 Konstytucji (zob. np. P. Sarnecki, Komentarz do art. 47, op. cit., s. 4; wyroki TK z: 21 października 1998 r., sygn. akt K 24/98; 11 kwietnia 2000 r., sygn. akt K 15/98; 20 listopada 2002 r., sygn. akt K 41/02; 20 marca 2006 r., sygn. akt K 17/05), który formułuje kumulatywnie ujęte przesłanki dopuszczalności ograniczeń w korzystaniu z konstytucyjnych praw i wolności. Są to: 1) ustawowa forma ograniczenia; 2) istnienie w państwie demokratycznym konieczności wprowadzenia ograniczenia; 3) funkcjonalny związek ograniczenia $\mathrm{z}$ realizacją wskazanych w art. 31 ust. 3 Konstytucji wartości (bezpieczeństwo państwa, porządek publiczny, ochrona środowiska, zdrowia i moralności publicznej, wolności i praw innych osób); 4) zakaz naruszania istoty danego prawa lub wolności (zob. np. wyrok TK z 30 maja 2007 r., sygn. akt SK 68/06; zob. również L. Garlicki, Komentarz do art. 31 [w:] Konstytucja Rzeczypospolitej Polskiej. Komentarz, t. III, red. L. Garlicki, Warszawa 2003, s. 14 i n.; J. Zakolska, Zasada proporcjonalności w orzecznictwie Trybunału Konstytucyjnego, Warszawa 2008, s. 115-141).

4. Zgodnie $\mathrm{z}$ art. 51 ust. 2 Konstytucji: „[w]ładze publiczne nie mogą pozyskiwać, gromadzić i udostępniać innych informacji o obywatelach niż niezbędne w demokratycznym państwie prawnym". Z tego, adresowanego do władz publicznych, przepisu wynika jednoznacznie, że dopuszczalne jest pozyskiwanie, gromadzenie i udostępnianie tylko takich informacji o obywatelach, które są niezbędne w demokratycznym państwie prawnym. Nie do końca jasne jest natomiast to, jakie informacje o obywatelach mogą być uznane za niezbędne w demokratycznym państwie prawnym. W doktrynie przyjmuje się, że chodzi tu o takie dane, które: „umożliwiają normalne funkcjonowanie jednostki w zorganizowanym w państwo społeczeństwie" i bez posiadania których władze publiczne nie są: „zdolne do podjęcia (czy zakończenia) działań w ramach przyznanych im kompetencji”. Nie będą więc niezbędne w demokratycznym państwie prawnym takie informacje o obywatelach, których pozyskiwanie, gromadzenie i udostępnianie służy jedynie „wygodzie” organów władzy publicznej, czy też, które są potrzebne tym organom „na wszelki wypadek”, np. gdyby dana osoba w przyszłości do- 
puściła się przestępstwa (zob. B. Banaszak, Konstytucja Rzeczypospolitej Polskiej. Komentarz, Warszawa 2012, komentarz do art. 51, nb. 6; I. Lipowicz, Komentarz do art. 51 [w:] Konstytucje Rzeczypospolitej oraz komentarz do Konstytucji RP z 1997 roku, red. J. Boć, Wrocław 1998, s. 99).

Jak podnosi Trybunał Konstytucyjny, art. 51 ust. 2 ustawy zasadniczej: „po pierwsze legalizuje - nieuchronne we współczesnym społeczeństwie - działania władz publicznych polegające na pozyskiwaniu, gromadzeniu i udostępnianiu informacji o jednostkach w sposób inny niż w drodze zgłoszenia takich danych przez samego obywatela, zobligowanego w trybie określonym w art. 51 ust. 1 Konstytucji. Po drugie [...] w sposób częściowo autonomiczny określa przesłanki legalności (granice) takich działań. Konstytucja realizuje jednak w ten sposób najbardziej zasadnicze elementy składające się na treść prawa do ochrony życia prywatnego: respekt dla autonomii informacyjnej jednostki, a więc sam obowiązek udostępnienia danych ograniczony do ściśle określonych ustawowo sytuacji; ograniczenie arbitralności ustawodawcy - ustawa nie może bowiem zakresu obowiązku kształtować dowolnie [...]. Zakres autonomii informacyjnej obejmuje zarówno dane o charakterze stricte personalnym (osobowym), jak i te dotyczące majątku i sfery ekonomicznej jednostki. W tym ostatnim zakresie Trybunał dopuszcza jednak łagodniejsze kryteria jej ograniczania niż w wypadku sfery czysto osobistej [...]" (wyrok TK z 17 czerwca 2008 r., sygn. akt K 8/04, i przywołane tam inne orzeczenia TK). Jednocześnie w art. 51 ust. 2 Konstytucji mowa jedynie o obywatelach w związku z czym władze publiczne mogą przetwarzać informacje dotyczące innych osób i dane poddane przetworzeniu nie muszą spełniać jednocześnie warunku niezbędności w demokratycznym państwie prawnym.

Zgodnie z art. 51 ust. 3 Konstytucji: „[k]ażdy ma prawo dostępu do dotyczących go urzędowych dokumentów i zbiorów danych. Ograniczenie tego prawa może określić ustawa”. Uprawnienie to jego ograniczone do „urzędowych” dokumentów oraz „urzędowych” zbiorów danych. W przypadku podmiotów niepublicznych podstawą uzyskania dostępu jest prawo do ochrony życia prywatnego (art. 47 Konstytucji). Przepis ten gwarantuje, że podstawą decydowania o statusie prawnym danej osoby nie mogą być jakiekolwiek dokumenty i informacje, które pozostawałyby niedostępne, jako tajne, dla samej osoby zainteresowanej czy dla sądu kontrolującego wydanie decyzji (wyroki TK z: 26 października 2005 r., sygn. akt K 31/04; 11 maja 2007 r., sygn. akt K 2/07; 27 czerwca 2008 r., sygn. akt K 51/07). Dostęp do akt sprawy przez strony postępowań oraz prawo żądania sprostowania lub usunięcia informacji nieprawdziwych, niepełnych lub zebranych w sposób sprzeczny z ustawą, zamieszczonych w aktach sprawy, w celu wydania indywidualnego rozstrzygnięcia, jest uznawany przez TK za jeden ze standardów sprawiedliwego postępowania administracyjnego (wyrok TK z 27 czerwca 2008 r., sygn. akt K 51/07). Zgodnie z orzecznictwem TK ograniczenie tego prawa (tj. odmowa dostępu) musi być uzasadniona doniosłym in- 
teresem publicznym, a ograniczenia tego prawa muszą czynić zadość zasadom proporcjonalności (wyrok TK z 26 października 2005 r., sygn. akt K 31/04).

Zgodnie $\mathrm{z}$ art. 51 ust. 4 Konstytucji: „[k]ażdy ma prawo do żądania sprostowania oraz usunięcia informacji nieprawdziwych, niepełnych lub zebranych w sposób sprzeczny z ustawą". Przyjmuje się, że przewiduje on uprawnienie każdej osoby do: „przedstawiania/kształtowania swego publicznego obrazu, rysującego się na tle danych zebranych przez władzę” i „obejmuje żądanie sprostowań oraz usunięcia informacji niepełnych, nieprawdziwych lub zebranych w sposób sprzeczny z ustawą" (wyrok TK z 12 grudnia 2005 r., sygn. akt K 32/04; zob. też wyrok TK z 23 czerwca 2009 r., sygn. akt K 54/07). Uwagę zwraca rygoryzm unormowania zawartego w art. 51 ust. 4 Konstytucji, gdyż nie przewiduje ono możliwości ograniczeń wprowadzanych w drodze ustawy zwykłej (zob. np. postanowienie TK z 25 stycznia 2006 r., sygn. akt S 2/06). Stąd wynika z niego obowiązek władzy publicznej, aby na poziomie ustawodawstwa zwykłego zagwarantować realizację unormowanego w tym przepisie aspektu prawa do prywatności, a tym bardziej nie naruszać go ani nie narażać na szkodę (np. wyrok TK z 26 października 2005 r., sygn. akt K 31/04). Nie są z niego wyłączone informacje zebrane $\mathrm{w}$ drodze działalności operacyjnej. Jednakże $\mathrm{z}$ uwagi na to, że: „dane pochodzące $z$ kontroli operacyjnej nie są ujawniane wobec zainteresowanego przy rozpoczęciu i w czasie trwania kontroli operacyjnej, przeto możliwość skorzystania z uprawnienia, o którym mowa w art. 51 ust. 4 Konstytucji de facto jest ograniczona" (wyrok TK z 12 grudnia 2005 r., sygn. akt K 32/04; zob. też wyrok TK z 23 czerwca 2009 r., sygn. akt K 54/07). W orzecznictwie TK zasadnie podnosi się, że żaden interes państwa nie może sankcjonować i usprawiedliwiać zachowywania w urzędowych dokumentach i zbiorach danych informacji nieprawdziwych, niepełnych czy zebranych w sposób sprzeczny z ustawą (wyroki TK z: 11 maja 2007 r., sygn. akt K 2/07; 20 października 2010 r., sygn. akt P 37/09), bowiem w interesie państwa - dla ochrony wartości konstytucyjnych - jest posiadanie informacji prawdziwych i możliwie pełnych. Jednocześnie w orzecznictwie wskazuje się, że istnieje pewien zakres informacji, które mogą nie rościć sobie prawa do kompletności, a jednak uwzględnienie żądania o ich sprostowanie bądź usunięcie stanowiłoby zakłócenie równowagi między interesem publicznym a interesem indywidualnym (postanowienie TK z 4 grudnia 2000 r., sygn. akt SK 10/99). Z informacjami zebranymi w sposób sprzeczny z ustawą zgodnie z orzecznictwem TK mamy do czynienia nie tylko wówczas, gdy uzyskiwanie danego rodzaju informacji jest w ogóle niedopuszczalne, ale również wtedy, gdy informacji nie pozyskano na podstawie i w granicach przewidzianych wyraźnie w ustawie lub gdy ich pozyskanie nastąpiło niezgodnie z określoną procedurą (wyrok TK z 30 lipca 2014 r., sygn. akt K 23/11). Należy także mieć na względzie - szczególnie w przypadku oceny konstytucyjności - że: „literalne brzmienie tego przepisu umieszczonego w samej Konstytucji wskazuje, że nacisk położono tu na sposób, w jaki zbierano materiały (a nie na kwestię ich 
wykorzystania w ewentualnym innym procesie, czemu ma służyć zachowanie zbioru)" (wyrok TK z 12 grudnia 2005 r., sygn. akt K 32/04).

5. Zgodnie z art. 31 ust. 3 Konstytucji: „[o]graniczenia w zakresie korzystania z konstytucyjnych wolności i praw mogą być ustanawiane tylko w ustawie i tylko wtedy, gdy są konieczne w demokratycznym państwie dla jego bezpieczeństwa lub porządku publicznego, bądź dla ochrony środowiska, zdrowia i moralności publicznej, albo wolności i praw innych osób. Ograniczenia te nie mogą naruszać istoty wolności i praw". Zasada proporcjonalności jest ściśle związana z założeniem racjonalnego działania prawodawcy, które stanowi punkt wyjścia podczas oceny zgodności kwestionowanych przepisów z Konstytucją. Cel podjęcia działania przez prawodawcę nie ogranicza się jedynie do wskazania pożądanego stanu faktycznego, ale wymaga odwołania się do wartości, które prawodawca obowiązany jest chronić, a zatem do systemu wartości wyrażonego w Konstytucji. Racjonalny prawodawca wybiera zatem cele służące najpełniejszej realizacji wyrażonego w Konstytucji systemu wartości, a następnie dobiera środki najbardziej adekwatne do realizacji tych celów. Za środki najbardziej adekwatne należy uznać te, które są, po pierwsze, skuteczne w realizacji pożądanego stanu faktycznego, a po drugie, zgodne z przyjętym systemem wartości. Tak rozumiany model racjonalności prawodawcy pozwala uznać, że funkcja prawa polega na realizacji wartości o podstawowym znaczeniu dla jednostki i społeczeństwa i nie sprowadza się do skutecznego sterowania procesami społecznymi (zob. K. Wojtyczek, Granice ingerencji ustawodawczej w sferę praw człowieka w Konstytucji RP, Kraków 1999, s. 137-139). Prawodawca, którego działania mieszczą się w takim ujęciu racjonalności, unika także zarzutu arbitralności swych działań (wyrok TK z 12 lutego 2014 r., sygn. akt K 23/10). W związku z tym wprowadza się trzy kryteria: przydatności, konieczności i proporcjonalności przyjmowanych ograniczeń (zob. K. Wojtyczek, Granice ingerencji, op. cit., s. 150 i n.).

$\mathrm{Z}$ zasady proporcjonalności Trybunał Konstytucyjny wyprowadził trzy powiązane między sobą obowiązki prawodawcy:

- przyjmowanie danej regulacji tylko wówczas, gdy jest niezbędna dla ochrony interesu publicznego, z którym jest związana,

- kształtowanie danej regulacji w sposób zapewniający osiągnięcie zamierzonych celów (skutków),

- zachowanie proporcji między efektami wprowadzonej regulacji a ciężarami bądź niedogodnościami wynikającymi z niej dla obywateli. Zasada ta kładzie szczególny nacisk na adekwatność celu i środka użytego do jego osiągnięcia. To znaczy, że spośród możliwych środków oddziaływania należałoby wybierać środki skuteczne dla osiągnięcia założonych celów, a zarazem jak najmniej uciążliwe dla podmiotów, wobec których mają być zastosowane, lub dolegliwe w stopniu nie większym niż jest to niezbędne dla osiągnięcia założonego celu (wyroki TK z: 18 października 2011 r., sygn. akt SK 2/10; 12 stycznia 2012 r., sygn. akt Kp 10/09; 23 maja 2012 r., sygn. akt P 11/10). 
Artykuł 31 ust. 3 Konstytucji: „wyznacza granice ingerencji władzy publicznej w sferę praw człowieka, nie udziela natomiast sam przez się ogólnego upoważnienia do ograniczania praw konstytucyjnych. [...] znajduje zastosowanie wtedy, gdy Konstytucja wyznacza zakres ochrony danego prawa, a jednocześnie w sposób wyraźny lub dorozumiany - dopuszcza ingerencję władz publicznych w sferę danego prawa chronioną konstytucyjnie. [...] nie znajduje natomiast zastosowania w tych wypadkach, gdy Konstytucja ogranicza się do wyznaczenia minimalnego zakresu ochrony danego prawa, który wiąże władze publiczne, a jednocześnie pozostawia ustawodawcy bardzo dużą swobodę przy urzeczywistnieniu tego prawa pod warunkiem poszanowania minimalnego zakresu danego prawa wynikającego z Konstytucji. W takim wypadku ustawodawca jest w praktyce związany przede wszystkim bezwzględnym zakazem naruszania istoty danego prawa” (wyrok TK z 23 lutego 2010 r., sygn. akt P 20/09).

6. Zgodnie $z$ art. 2 Konstytucji: „Rzeczpospolita Polska jest demokratycznym państwem prawnym, urzeczywistniającym zasady sprawiedliwości społecznej”. Wskazany przepis ustanawia zasadę demokratycznego państwa prawnego, której treść jest bardzo bogata. Założeniem państwa prawnego jest wykonywanie władzy państwowej jedynie wtedy, gdy zezwala na to Konstytucja oraz ustawy, zgodne $\mathrm{z}$ nią pod względem formalnym i materialnym, a celem wykonywania tej władzy jest ochrona ludzkiej godności, sprawiedliwości i pewności prawa (E. Morawska, Klauzula państwa prawnego w Konstytucji RP na tle orzecznictwa Trybunału Konstytucyjnego, Toruń 2003, s. 60). Klauzula ta stanowi podstawę do wyprowadzenia z niej katalogu zasad konstytucyjnych niesformułowanych wprost w przepisach. Zasady te dotyczą przede wszystkim stanowienia prawa. Istnieje stały katalog tych zasad wywodzony przede wszystkim z zasady zaufania osoby do państwa i stanowionego przez nie prawa. W doktrynie wskazuje się, że katalog ten ma charakter otwarty, tj. istnieje możliwość wyprowadzenia przez Trybunał Konstytucyjny $\mathrm{z}$ art. 2 Konstytucji nowej zasady pochodnej.

$\mathrm{Z}$ art. 2 Konstytucji wywodzone są w orzecznictwie Trybunału zasady pochodne, w tym jest on źródłem zasady zaufania obywatela do państwa. Zgodnie z orzecznictwem TK: „[z]asada ochrony zaufania wyznacza sytuację prawną nie tylko obywateli, lecz także chroni przed ingerencją władzy państwowej inne podmioty stosunków prawnych" (wyrok TK z 31 stycznia 2001 r., sygn. akt P 4/99). Nazywana jest ona także zasadą lojalności państwa względem obywateli, jest jedną z najważniejszych zasad pochodnych, wynikających z zasady demokratycznego państwa prawnego (zob. np. wyrok TK z 20 grudnia 1999 r., sygn. akt K 4/99; W. Sokolewicz, M. Zubik, Komentarz do art. 2 [w:] Konstytucja Rzeczypospolitej Polskiej. Komentarz, t. I, red. L. Garlicki, M. Zubik, Warszawa 2016, s. 127 i n.). „W dotychczasowym orzecznictwie TK ugruntowane zostało stanowisko, iż art. 2 Konstytucji obejmuje również zasadę ochrony zaufania do państwa i stanowionego przez nie prawa. Jest ona - jak podkreślano we wcześniejszych orzeczeniach - oczywistą cechą demokratycznego państwa prawnego, 
bowiem „demokratyczne państwo prawne oznacza państwo, w którym chroni się zaufanie do państwa i stanowionego przez nie prawa". Zasada ta oznacza przede wszystkim konieczność ochrony i respektowania praw słusznie nabytych i ochrony interesów w toku (por. m.in. orzeczenie TK z 2 marca 1993 r., sygn. akt K 9/92), ale obejmuje jednocześnie zakaz tworzenia przez ustawodawcę takich konstrukcji normatywnych, które są niewykonalne, stanowią złudzenie prawa i w konsekwencji jedynie pozór ochrony tych interesów majątkowych, które są funkcjonalnie związane z treścią ustanowionego prawa podmiotowego" (wyroki TK z: 19 grudnia 2002 r., sygn. akt K 33/02; 25 listopada 1997 r., sygn. akt K 26/97; 13 kwietnia 1999 r., sygn. akt K 36/98). Zasada ta nie ma charakteru bezwzględnego, bowiem są od niej dopuszczalne wyjątki (wyrok TK z 12 maja 2015 r., sygn. akt P 46/13).

7. Zgodnie z art. 7 Konstytucji: „[o]rgany władzy publicznej działają na podstawie i w granicach prawa”. Przywołany przepis wyraża zarówno zasadę legalizmu w wąskim znaczeniu, nakaz działania na podstawie prawa, jak i obowiązek przestrzegania prawa (zob. W. Sokolewicz, Komentarz do art. 7 [w:] Konstytucja Rzeczypospolitej Polskiej. Komentarz, t. V, red. L. Garlicki, Warszawa 2007, s. 3). Nakaz wyrażony w art. 7 Konstytucji adresowany jest do organów władzy publicznej. Zgodnie z orzecznictwem Trybunału Konstytucyjnego „pojęcie „władzy publicznej” w rozumieniu art. 77 ust. 1 Konstytucji obejmuje wszystkie władze w sensie konstytucyjnym - ustawodawczą, wykonawczą i sądowniczą. Należy podkreślić, że pojęcia organu państwa oraz organu władzy publicznej nie są tożsame. W pojęciu „władzy publicznej” mieszczą się bowiem także inne instytucje niż państwowe lub samorządowe, o ile wykonują funkcje władzy publicznej w wyniku powierzenia czy przekazania im tych funkcji przez organ władzy państwowej lub samorządowej. Wykonywanie władzy publicznej dotyczy wszelkich form działalności państwa, samorządu terytorialnego i innych instytucji publicznych, które obejmują bardzo zróżnicowane formy aktywności. Wykonywanie takich funkcji łączy się z reguły, chociaż nie zawsze, z możliwością władczego kształtowania sytuacji jednostki. Dotyczy to obszaru, na którym może dojść do naruszenia praw i wolności jednostki ze strony władzy publicznej. Nazwa „organ” władzy publicznej użyta w art. 77 ust. 1 Konstytucji oznacza instytucję, strukturę organizacyjną, jednostkę władzy publicznej, z której działalnością wiąże się wyrządzenie szkody, nie zaś organ osoby prawnej w kategoriach prawa cywilnego. Odpowiedzialność oparta na tym przepisie obciąża strukturę (instytucję), a nie osoby z nią związane (jej funkcjonariuszy). Podstawowe znaczenie ma ustalenie, czy działanie organu władzy publicznej związane jest $\mathrm{z}$ realizacją jego prerogatyw. Formalny charakter powiązań pomiędzy bezpośrednim sprawcą szkody a władzą publiczną jest mniej istotny. Ustalenie statusu osoby, która jest bezpośrednim sprawcą szkody, ułatwia jednak przypisanie danego działania organowi władzy publicznej" (wyrok TK z 4 grudnia 2001 r., sygn. akt SK 18/00). 
Podobnie Trybunał Konstytucyjny wskazał, że: „pojęcie «działania» organu władzy publicznej nie zostało konstytucyjnie zdefiniowane. W pojęciu tym mieszczą się zarówno zachowania czynne tego organu, jak i zaniechania. W zakresie działań czynnych organu władzy publicznej mieszczą się indywidualne rozstrzygnięcia, np. decyzje, orzeczenia i zarządzenia. Pojęcie «zaniechania» władzy publicznej dotyczy tych sytuacji, w których obowiązek określonego działania władzy publicznej jest skonkretyzowany w przepisie prawa i można ustalić, na czym konkretnie miałoby polegać zachowanie organu władzy publicznej” (wyrok TK z 4 grudnia 2001 r., sygn. akt SK 18/00).

Jak wskazał Trybunał Konstytucyjny: „stosownie do art. 7 Konstytucji, organy władzy publicznej działają na podstawie i w granicach prawa. Oznacza to m.in., że kompetencje organów władzy publicznej powinny zostać jednoznacznie i precyzyjnie określone w przepisach prawa, wszelkie działania tych organów powinny mieć podstawę $\mathrm{w}$ takich przepisach, a - w razie wątpliwości interpretacyjnych - kompetencji organów władzy publicznej nie można domniemywać" (wyrok TK z 14 czerwca 2006 r., sygn. akt K 53/05). Podobnie w postanowieniu z 4 października 2011 r., sygn. akt P 9/11, Trybunał Konstytucyjny stwierdził, że: „zgodnie z art. 7 Konstytucji, organy władzy publicznej działają na podstawie i w granicach prawa. Oznacza to powinność organu władzy publicznej przestrzegania wszystkich przepisów, niezależnie od usytuowania ich w systemie źródeł prawa, które określają jego uprawnienia lub obowiązki. Organy muszą zatem znać przepisy regulujące ich kompetencje i stosować się do wynikających z nich nakazów i zakazów. Z konstytucyjnej zasady legalizmu wynika zatem, że nie mogą podejmować działań bez podstawy prawnej czy unikać wykonania kompetencji, jeżeli wiążące normy prawne nakładają na te organy określone obowiązki (por. wyrok TK z 21.02.2001 r., sygn. P 12/00)”. Wreszcie z art. 7 Konstytucji wynika domniemanie, że organy władzy publicznej działają na podstawie i w granicach prawa. Domniemanie to może zostać obalone w przewidzianych przez prawo formach, w szczególności poprzez stwierdzenie przez Trybunał Konstytucyjny naruszenia przez organ władzy publicznej art. 7 Konstytucji.

8. Zgodnie z art. 40 Konstytucji: „[n]ikt nie może być poddany torturom ani okrutnemu, nieludzkiemu lub poniżającemu traktowaniu i karaniu. Zakazuje się stosowania kar cielesnych". W przepisie tym występuje pewien ciąg określeń, wykluczających wiele zachowań ludzkich, określeń bliskoznacznych, z wyraźną intencją uczynienia nielegalnymi działań wymierzonych przeciwko samej naturze człowieka i tym samym jego godności (zob. P. Sarnecki, Komentarz do art. 40 [w:] Konstytucja Rzeczypospolitej Polskiej. Komentarz, t. III, red. L. Garlicki, Warszawa 2003, s. 1).

Przy definiowaniu pojęć, którymi posłużył się ustrojodawca w art. 40 Konstytucji, oraz zakresu i głębokości ustanowionego w tym przepisie zakazu warto odwołać się do właściwych aktów prawa międzynarodowego, a także ustaleń orzecznictwa i doktryny poczynionych na ich gruncie (zob. B. Banaszak, Konsty- 
tucja Rzeczypospolitej Polskiej. Komentarz, Warszawa 2009, komentarz do art. 40, s. 219; M. Królikowski, K. Szczucki, Komentarz do art. 40 [w:] Konstytucja RP. Komentarz, t. I, Art. 1-86, red. M. Safjan, L. Bosek, Warszawa 2016, nb. 25; P. Sarnecki, Komentarz do art. 40, op. cit., s. 1-3; J. Sobczak, Komentarz do art. 4 [w:] Karta praw podstawowych Unii Europejskiej. Komentarz, red. A. Wróbel, Warszawa 2013, nb. 9).

Zgodnie $\mathrm{z}$ art. 1 ust. 1 Konwencji w sprawie zakazu stosowania tortur oraz innego okrutnego, nieludzkiego lub poniżającego traktowania albo karania $\mathrm{z}$ dnia 10 grudnia 1984 r. (Dz.U. 1989, Nr 63, poz. 378) „tortury” oznaczają każde działanie, którym jakiejkolwiek osobie umyślnie zadaje się ostry ból lub cierpienie, fizyczne bądź psychiczne, w celu uzyskania od niej lub od osoby trzeciej informacji lub wyznania, w celu ukarania jej za czyn popełniony przez nią lub osobę trzecią albo o którego dokonanie jest ona podejrzana, a także w celu zastraszenia lub wywarcia nacisku na nią lub trzecią osobę albo w jakimkolwiek innym celu wynikającym z wszelkiej formy dyskryminacji, gdy taki ból lub cierpienie powodowane są przez funkcjonariusza państwowego lub inną osobę występującą $\mathrm{w}$ charakterze urzędowym lub $\mathrm{z}$ ich polecenia albo za wyraźną lub milczącą zgodą. Określenie to nie obejmuje bólu lub cierpienia wynikających jedynie ze zgodnych z prawem sankcji, nieodłącznie związanych z tymi sankcjami lub wywołanych przez nie przypadkowo.

Wymienione w art. 40 Konstytucji okrutne, nieludzkie traktowanie i karanie obejmuje: „oprócz zadawania bólu fizycznego czy psychicznego stwarzanie sytuacji dolegliwych także z innych względów, np. moralnych, religijnych czy obyczajowych", traktowanie i karanie poniżające zaś: „polega na zamachach, wymierzonych w godność człowieka, na zmuszaniu go do zachowań ośmieszających, upadlających, czy w ogóle sprawiających wrażenie wyrzekania się człowieczeństwa" (zob. P. Sarnecki, Komentarz do art. 40, op. cit., s. 2; B. Banaszak, Konstytucja, op. cit., s. 220).

Zwraca się również uwagę, że ustalenie tego, w czym się wyraża na przykład okrutność traktowania, może być w konkretnym wypadku kwestią ocen, które to oceny nie będą jednak całkowicie dowolne, ponieważ w kręgu kulturowym, do którego należy Polska, poglądy na ten temat są dość sprecyzowane i ustabilizowane (P. Winczorek, Komentarz do Konstytucji Rzeczypospolitej Polskiej z dnia 2 kwietnia 1997 roku, Warszawa 2008, s. 100-101).

9. Artykuł 3 Konwencji o ochronie praw człowieka i podstawowych wolności sporządzonej w Rzymie dnia 4 listopada 1950 r. (Dz. U. 1993, Nr 61, poz. 284, ze zm., dalej: EKPC) stanowi natomiast, że: „[n]ikt nie może być poddany torturom ani nieludzkiemu lub poniżającemu traktowaniu albo karaniu”. Treścią art. 3 EKPC jest wprowadzenie zakazu poddawania człowieka traktowaniu sprzecznemu z naturą godności ludzkiej, w szczególności powodującego cierpienia fizyczne i (lub) psychiczne, co można określić ogólnie jako zakaz maltretowania. Zakaz ten odnosi się zarówno do karania (rozumianego jako nakładanie sankcji 
przewidzianych przez prawo), jak i do wszelkich form faktycznego traktowania, powodujących - bezpośrednio lub pośrednio - takie skutki i pozostających w sferze odpowiedzialności państwa (władz publicznych) - (zob. L. Garlicki, Komentarz do art. 3 [w:] Konwencja o ochronie praw człowieka i podstawowych wolności, t. I, Komentarz do artykułów 1-18, red. L. Garlicki, Warszawa 2010, nb. 1).

Nieludzkie traktowanie w rozumieniu art. 3 EKPC polega na takim wkroczeniu w sferę integralności fizycznej i psychicznej człowieka, które - nie sięgając swoją drastycznością poziomu tortury - przekracza dolegliwości w sposób nieunikniony związane ze zgodną z prawem realizacją przez funkcjonariuszy zadań i obowiązków o legitymowanym charakterze. Obecne orzecznictwo orientuje się nie tylko na kryterium intensywności cierpienia, ale także na kryterium konieczności zastosowania siły fizycznej. Rozszerzyło to zakres sytuacji, które wobec braku tej konieczności kwalifikuje się jako nieludzkie traktowanie.

Tak rozumiane nieludzkie traktowanie pojawia się, przede wszystkim, w sytuacji zatrzymań policyjnych. Niepotrzebne i ekscesywne użycie siły zawsze może zostać uznane za nieludzkie traktowanie: „[a]rt. 3 nie zakazuje użycia siły w celu dokonania zatrzymania. Niemniej, użycie siły jest dopuszczalne tylko, gdy jest nieodzowne i nie może mieć nadmiernego charakteru" (wyrok ETPC z 3 listopada 2009 r., Staszewska v. Polska, skarga nr 10049/04).

$\mathrm{O}$ nieludzkim traktowaniu można mówić ponadto w szczególności w wypadkach użycia siły w związku z tłumieniem zamieszek czy innych, związanych z użyciem przemocy, zachowań grup ludzi, przejawami brutalności wobec osób już zatrzymanych oraz w odniesieniu do traktowania więźniów w tym bezzasadnego używania siły. Traktowanie poniżające polega natomiast na takim wkroczeniu w sferę integralności fizycznej i/lub psychicznej człowieka, które wywołuje u ofiary odczucia strachu, stresu i podporządkowania, zdolne do jej upokorzenia i upodlenia/zniewolenia. Znaczenie zasadnicze ma element subiektywny, tzn. sposób recepcji działań przez osobę im poddawaną. Odczucia poniżenia mogą ulec wzmocnieniu, gdy działania wobec ofiary podejmowane są w sposób pozwalający publiczności (środkom masowego przekazu) ich obserwację i relacjonowanie (zob. szerzej L. Garlicki, Komentarz do art. 3, op. cit., nb. 17 i n., wraz z przywołanym tam orzecznictwem).

Należy zwrócić uwagę, że w toku ewolucyjnej wykładni poszerzono zakres obowiązków wynikających z art. 3 EKPC. Obok, podstawowego (materialnego), obowiązku o charakterze negatywnym (zakazującego władzom i ich funkcjonariuszom dopuszczania się działań o maltretującym charakterze), orzecznictwo zaczęło wydobywać obowiązki proceduralne, nakazujące władzom przeprowadzenie „efektywnego badania” wszelkich zarzutów maltretowania (L. Garlicki, Komentarz do art. 3, op. cit., nb. 9). Każde pojawienie się zarzutu maltretowania zobowiązuje władze krajowe do przeprowadzenia dochodzenia mającego na celu ustalenie faktów i ukaranie ewentualnych sprawców. Obowiązek ten dotyczy przede wszystkim sytuacji, gdy ofiara maltretowania złożyła stosowną skargę lub 
zawiadomienie. Także jednak, gdy władza publiczna powzięła z urzędu wiadomość o fakcie maltretowania, jest obowiązana do wdrożenia dochodzenia lub przekazania sprawy właściwemu organowi.

10. Zgodnie z art. 6 EKPC: „1. Każdy ma prawo do sprawiedliwego i publicznego rozpatrzenia jego sprawy $\mathrm{w}$ rozsądnym terminie przez niezawisły i bezstronny sąd ustanowiony ustawą przy rozstrzyganiu o jego prawach i obowiązkach o charakterze cywilnym albo o zasadności każdego oskarżenia w wytoczonej przeciwko niemu sprawie karnej. Postępowanie przed sądem jest jawne, jednak prasa i publiczność mogą być wyłączone z całości lub części rozprawy sądowej ze względów obyczajowych, z uwagi na porządek publiczny lub bezpieczeństwo państwowe $\mathrm{w}$ społeczeństwie demokratycznym, gdy wymaga tego dobro małoletnich lub gdy służy to ochronie życia prywatnego stron albo też w okolicznościach szczególnych, w granicach uznanych przez sąd za bezwzględnie konieczne, kiedy jawność mogłaby przynieść szkodę interesom wymiaru sprawiedliwości. 2. Każdego oskarżonego o popełnienie czynu zagrożonego karą uważa się za niewinnego do czasu udowodnienia mu winy zgodnie z ustawą. 3. Każdy oskarżony o popełnienie czynu zagrożonego karą ma co najmniej prawo do: a) niezwłocznego otrzymania szczegółowej informacji w języku dla niego zrozumiałym o istocie i przyczynie skierowanego przeciwko niemu oskarżenia; b) posiadania odpowiedniego czasu i możliwości do przygotowania obrony; c) bronienia się osobiście lub przez ustanowionego przez siebie obrońcę, a jeśli nie ma wystarczających środków na pokrycie kosztów obrony - do bezpłatnego korzystania z pomocy obrońcy wyznaczonego z urzędu, gdy wymaga tego dobro wymiaru sprawiedliwości; d) przesłuchania lub spowodowania przesłuchania świadków oskarżenia oraz żądania obecności i przesłuchania świadków obrony na takich samych warunkach jak świadków oskarżenia; e) korzystania z bezpłatnej pomocy tłumacza, jeżeli nie rozumie lub nie mówi językiem używanym w sądzie". W związku z tym przepis ten gwarantuje: „1) sprawiedliwość proceduralną (procedural fairness) w postępowaniach w sprawach cywilnych i karnych, 2) prawo dostępu do sądu celem dochodzenia praw i obowiązków cywilnoprawnych, 3) prawo do wykonania wyroku w sprawie cywilnej (Human Rights Practice, Londyn 2006, Article 6 Right to a Fair Trial, M. Purchase, E. Schutzer-Weismann, s. 6.001-6.002). Według innego poglądu, gwarancje zawarte $\mathrm{w}$ art. 6 to: 1) gwarancje organizacyjne (niezawisły i bezstronny sąd ustanowiony ustawą), 2) prawo dostępu do sądu, 3) gwarancje rzetelnego postępowania w węższym znaczeniu (Ch. Grabenwarter, Europäische Menschenrechtskonvention, München-Basel-Wien 2008, s. 660)" (P. Hofmański, A. Wróbel, Komentarz do art. 6 [w:] Konwencja o ochronie praw człowieka $i$ podstawowych wolności, t. I, Komentarz do artykułów 1-18, red. L. Garlicki, Warszawa 2010, nb. 5). Uprawnienia zawarte w tym przepisie tworzą tzw. minimalny standard praw oskarżonego. „[... Prawo do obrony, w zakresie gwarantowanym przez przepisy EKPC nie jest jednak prawem absolutnym. Wskazuje 
na to również ETPC, podkreślając, że zakres realizacji także i tego prawa musi być oceniany w kontekście wszystkich okoliczności sprawy, w szczególności zaś nakazuje uwzględnienie innych prawnie chronionych wartości, oraz realizację praw wszystkich jego uczestników” (P. Karlik, T. Sroka, P. Wiliński, Komentarz do art. 42, op. cit., nb. 201-203).

\section{- Analiza zgodności}

1. Oceniając zaskarżony przez Rzecznika przepis, należy mieć na względzie zarówno dobro wymiaru sprawiedliwości, jak też to, że z każdym przestępstwem wiąże się krzywda lub szkoda innej osoby lub zbiorowości. Stąd ustawodawca zwykły ma obowiązek takiego ukształtowania procesu karnego, by sprawca przestępstwa mógł zostać pociągnięty do odpowiedzialności i poniósł zasłużoną karę. Taka jest też ratio legis art. 168a k.p.k., który ma na celu zagwarantowanie, że każdy dowód zostanie poddany ocenie przez sąd rozpoznający sprawę karną odnośnie do jego treści i wiarygodności. Stanowi to jedną z gwarancji rzetelnego procesu sądowego i wydania sprawiedliwego wyroku. Odnosząc się do doktryny owoców zatrutego drzewa, do której odwołuje się Rzecznik, wskazać należy, że praktyka krajów, w których jest ona przyjęta, dowodzi, że nie przyniosła ona realizacji celów, którymi uzasadniano jej wprowadzenie (por. stanowisko Prokuratora Generalnego, s. 92 i n. oraz powoływana tam literatura przedmiotu). D. Osborn wskazuje, że poza Stanami Zjednoczonymi, także w Australii, Kanadzie i Wielkiej Brytanii: „wykluczanie istotnych dowodów uzyskanych nielegalnie nie gwarantuje sprawiedliwego procesu, lecz wypacza wymiar sprawiedliwości. Ponadto, konieczność wykluczania nielegalnie uzyskanych dowodów burzy stabilność orzecznictwa oraz wywołuje niezrozumienie wśród opinii publicznej (D. Osborn, Suppressing the Truth: Judicial Exclusion of Illegally Obtained Evidence in the United States, Canada, England and Australia, Murdoch University Electronic Journal of Law, http://www.austlii.edu.au/au/joumals/MurUEJL/2000/44.html, teza 70-86)" (ibidem, s. 93). Negatywne skutki procesowe stosowania doktryny owoców zatrutego drzewa spowodowały ograniczenie zakresu jej stosowania w amerykańskim procesie karnym. Uczynił tak Sąd Najwyższy Stanów Zjednoczonych „w wyrokach z dnia 15 czerwca 2006 r. w sprawie Hudson v. Michigan (https://www.supremecourt.gov/opinions/05pdf/04-1360. pdf), z dnia 14 stycznia 2009 w sprawie Herring v. United States (https://wvvw. law.comell.edu/supct/pdf/07-513P.ZO) oraz z dnia 20 czerwca 2016 r. w sprawie Utah v. Strieff (https://www. supremecourt.gov/opinions/15pdf/14-1373_83i7. pdf)" (ibidem). Przy ocenie art. 168a k.p.k. te negatywne doświadczenia państw anglosaskich, wskazujące, że wskutek stosowania doktryny owoców zatrutego drzewa wymiar sprawiedliwości niejednokrotnie pozbawia się możliwości wymierzania sprawiedliwości, muszą być wzięte pod uwagę. Podobnie jak to, że zarówno tamtejsza doktryna, jak i orzecznictwo odchodzą od takiego rozumienia tej doktryny, która jest obecna we wniosku Rzecznika. 
Rozważenia wymaga także, czy w kwestionowanych przez Rzecznika przepisach mamy do czynienia z kolizją praw czy wartości uznawanych przez Konstytucję, czy też nie. Pojęcie kolizji praw rozumiane jest przy tym w orzecznictwie TK szerzej i obejmuje również sytuacje, gdy urzeczywistnienie prawa określonego podmiotu w danej sytuacji faktycznej powoduje jedynie niebezpieczeństwo naruszenia prawa innego podmiotu (zob. m.in. wyroki TK z: 5 maja 2004 r., sygn. akt P 2/03; 12 maja 2008 r., sygn. akt SK 43/05). W każdym takim wypadku konieczne jest dokonanie oceny z punktu widzenia kompromisu między wszystkimi konstytucyjnymi wartościami pozostającymi w konflikcie. Konstytucja przez konstrukcję proporcjonalności dopuszcza bowiem redukcję zakresu konkurencyjnych praw i wolności, ale nie zniweczenie ochrony któregoś z nich (wyrok TK z 25 listopada 2008 r., sygn. akt K 5/08). Trybunał Konstytucyjny wskazał, że w sytuacji kolizji konstytucyjnych wartości, praw i wolności zasadnicze znaczenie ma wyznaczenie proporcji ochrony i gwarancji każdego z chronionych dóbr, wolności i praw (wyrok TK z 9 listopada 2010 r., sygn. akt K 13/07). Gwarancje praw oskarżonego w procesie karnym jako ratio legis nie mają na celu ułatwienia sprawcy przestępstwa uniknięcia odpowiedzialności karnej, lecz zagwarantowanie osobie niewinnej, że nie zostanie skazana. Uwzględniając spójność aksjologiczną Konstytucji, nie można wyprowadzić z niej - jak wskazuje Rzecznik - normy prawnej nakazującej ułatwienie sprawcy przestępstwa skutecznej obrony, rozumianej jako zapewnienie przez państwo takich warunków obrony, żeby sprawca przestępstwa mógł uwolnić się od odpowiedzialności karnej za jego dokonanie. Taka wykładnia przywoływanych przez Rzecznika wzorców kontroli stanowiłaby nadużycie praw i wolności, które na poparcie swojego stanowiska przywołał on we wniosku. Wskazuje się w literaturze, że pojęcie „nadużycia prawa” oznacza zastosowanie (użycie) danego narzędzia prawnego sprzecznie z celem, dla którego zostało ono utworzone, sprzecznie z jego przeznaczeniem (M. Warchoł, Pojęcie „nadużycia prawa” w prawie procesowym, „Prokuratura i Prawo” 2007, nr 11, s. 48-67). Wobec czego z przypadkiem nadużycia prawa będziemy mieć do czynienia w razie, gdy prawo: „nie jest wykorzystywane do zadośćuczynienia interesom pożądanym przez ustawę, lecz do osiągnięcia celu nie godnego aprobaty" (U. Weber, Der MißbrauchprozessualerRechte im Strafverfahren, GA 1975, s. 289 [za:] M. Warchoł, Pojęcie "nadużycia prawa”, op. cit., s. 48). Niektórzy autorzy słusznie stwierdzają, że o nadużyciu możemy mówić zawsze wtedy, gdy dane uprawnienie jest wykonywane w sposób, który narusza ratio normy prawnej, które ustawodawca w niej zamieścił celem przestrzegania go, oraz takie użycie danego prawa, które ma wpływ na sferę interesów innych podmiotów (F. Cordopatri, L'abuso del processo. Diritto positivo, Padova 2000, s. 90; C. Conti, L'imputato nel procedimento connesso. Diritto al silenzio e obbligo di verità, Cedam 2003, s. 152 [za:] M. Warchoł, Pojęcie „nadużycia prawa”, op. cit., s. 48). Inaczej rzecz ujmując, w tym wypadku nadużyciem prawa i wolności przywoływanych przez Rzecznika na poparcie swojego wniosku jest rozciągnięcie ich na obszary nimi nie obję- 
te, do stopnia sprzeciwiającego się sensowi i uzasadnieniu aksjologicznemu tych prawa i wolności. Wykładnia praw i wolności konstytucyjnych, którą proponuje Rzecznik, prowadzi w praktyce do celu niegodnego aprobaty z punktu widzenia wartości i celów wyrażonych przez ustrojodawcę, dlatego musi być uznana za niedopuszczalną. W praktyce wykładnia ta w wielu wypadkach utrudniałaby lub uniemożliwiałaby pociągnięcie do odpowiedzialności sprawcy przestępstwa i wydanie sprawiedliwego wyroku. Należy bowiem pamiętać, że dowód stanowi jedynie nośnik informacji. Wady istniejące przy jego pozyskaniu nie wpływają na rzeczywisty przebieg zdarzeń, który miał miejsce, i nie muszą wpływać na wiarygodność dowodu. Stąd też zasadne jest dla rzetelności procesu sądowego i wydania sprawiedliwego wyroku poddanie takiego dowodu ocenie sądu.

Kwestionowane przez Rzecznika rozwiązanie stanowi także realizację konstytucyjnego obowiązku państwa, by: „działaniu instytucji publicznych zapewnić rzetelność i sprawność”. Oceniając art. 168a k.p.k., należy mieć na względzie zasadę dobra wspólnego. Zgodnie z art. 1 Konstytucji: „Rzeczpospolita Polska jest dobrem wspólnym wszystkich obywateli”. W orzecznictwie TK dobro wspólne jest wprost przywoływane jako racja lub jedna $\mathrm{z}$ racji uzasadniających ograniczenie wolności i praw konstytucyjnych czy jako aksjologiczna podstawa - wskazywanych w klauzulach limitacyjnych - racji ograniczania konstytucyjnych wolności i praw. Trybunał Konstytucyjny stwierdził, że: „uważa za fakt niewątpliwy, że pierwszą przyczyną, dla której prawa jednostki mogą być ograniczane jest ochrona dobra wspólnego [...]. W świetle tego przepisu, któremu - zważywszy na systematykę konstytucji - została nadana najwyższa ranga, nie może budzić wątpliwości, że zapewnienie bezpieczeństwa państwa jest celem usprawiedliwiającym ograniczenia wszelkich praw i wolności obywatelskich" (wyrok TK z 3 lipca 2001 r., sygn. akt K 3/01; zob. także wyroki TK z: 25 listopada 2003 r., sygn. akt K 37/02; 16 kwietnia 2002 r., sygn. akt SK 23/01). W tym samym orzeczeniu uznał też, że ochrona dobra wspólnego może stanowić rację wprowadzenia uregulowań: „które niewątpliwie ograniczają prawa jednostek i całych społeczności”. Tymczasem w argumentacji Rzecznika zawartej we wniosku wyraźnie widać przeciwstawianie praw człowieka dobru wspólnemu. Takie rozumienie praw i wolności jest nieuprawnione na gruncie Konstytucji. W praktyce Rzecznik neguje uznany przez TK obowiązek „dostatecznej ochrony określonych wartości konstytucyjnych”, który to obowiązek: „obliguje ustawodawcę zwykłego do wprowadzenia określonych środków służących ochronie tych wartości” (wyrok TK z 25 maja 1996 r., sygn. akt K 26/96). Trybunał Konstytucyjny w swoim orzecznictwie wskazał również, że powiązane z dobrem wspólnym poczucie sprawiedliwości wymaga karania przestępców i odpowiedzialności za czyny naruszające przepisy prawa karnego (wyroki TK z: 25 maja 2004 r., sygn. akt SK 44/03; 15 października 2008 r., sygn. akt P 32/06).

2. Rzecznik wywodzi, że art. 168a k.p.k. jest niezgodny $z$ art. 2, w tym zwłaszcza z zasadą zaufania obywateli do państwa i stanowionego przez nie prawa. 
Stanowić ma bowiem podstawę do: „podejmowania czynności działających na niekorzyść jednostki” (wniosek Rzecznika, s. 21). Uwzględniając poczynione już uprzednio w poprzednim punkcie rozważania, Sejm pragnie podkreślić, że stosowanie w procesie karnym exclusionary rule (zasady wykluczania) i doktryny „owoców zatrutego drzewa”, za czym opowiada się Rzecznik, podważałoby zaufanie obywateli do państwa i stanowionego przez nie prawa, w szczególności kryzys zaufania dotknąłby władzę sądowniczą. Trudno bowiem przyjąć, że zaufanie praworządnego obywatela miałoby budować uniknięcie odpowiedzialności przez sprawcę przestępstwa tylko ze względów formalnych. Nie jest to jedynie zagrożenie potencjalne, gdyż stosowanie tych zasad: „doprowadziło do kryzysu wiary opinii publicznej w system wymiaru sprawiedliwości [w Stanach Zjednoczonych - dopisek A.P.] (vide D. Osborn, Suppressing the Truth: Judicial Exclusion of Illegally Obtained Evidence in the United States, Canada, England and Australia, Murdoch University Electronic Journal of Law, http://www.austlii. edu.au/au/journals/MurUEJL/2000/44.html, teza 68)" (stanowisko Prokuratora Generalnego, s. 111).

Przypomnieć należy, że państwo stanowi wynik umowy społecznej, poprzez którą: „obywatele zrzekli się części prerogatyw osobistych na rzecz Państwa, w tym prawa do samodzielnego wymierzania sprawiedliwości. Trudno jest mówić o lojalności państwa względem obywatela, jeśli państwo zabrania obywatelowi samodzielnego wymierzenia sprawiedliwości sprawcy przestępstwa popełnionego na szkodę tegoż obywatela, a jednocześnie samo odmawia ukarania owego sprawcy, ponieważ w toku zbierania materiału dowodowego uchybiono np. prawu do ochrony autonomii informacyjnej oskarżonego" (ibidem). Taki stan rzeczy stanowiłby niezgodną z konstytucyjną zasadą ochrony zaufania obywateli do państwa i stanowionego przez nie prawa pułapkę zastawioną na praworządnych obywateli pokrzywdzonych przez sprawców przestępstw. Pokrzywdzony obywatel owszem - na wzór Stanów Zjednoczonych - mógłby dochodzić swoich praw w procesie cywilnym, jednakże droga taka jest kosztowna oraz powoduje wtórną wiktymizację pokrzywdzonego. Co więcej, w większości przypadków byłaby także nieskuteczna, bowiem z dużym prawdopodobieństwem można przyjąć, że sąd cywilny oparłby się na ustaleniach sądu karnego. Prokurator Generalny w swoim stanowisku słusznie wykazuje, że państwo ma obowiązek zachowywania zawartej z obywatelami umowy społecznej, a więc m.in. wykrywania i pociągania do odpowiedzialności karnej sprawców przestępstw oraz zapewniania, że nie poniesie tej odpowiedzialności osoba niewinna. Przyjęcie doktryny owoców zatrutego drzewa godzi w realizację tego celu, co jest niebezpiecznie dla porządku społecznego, bowiem: „w skrajnych przypadkach może prowadzić do samosądów, które w istocie są skrajną emanacją braku zaufania obywateli do wymiaru sprawiedliwości, stanowią klęskę systemu zwalczania przestępczości oraz mogą skutkować drastycznymi naruszeniami najistotniejszych praw obywateli wskutek działań innych obywateli” (ibidem, s. 112). Oprócz tego pamiętać na- 
leży, że zgodnie z preambułą Konstytucji Rzeczypospolita Polska jest państwem opartym „na poszanowaniu [...] sprawiedliwości [...]”. W art. 2 Konstytucji wyrażono nakaz urzeczywistniania zasad sprawiedliwości społecznej. Wydaje się zasadne, że przyjęcie, iż jednym z elementów zasady sprawiedliwości jest możliwość skutecznego karania sprawców przestępstw. Skoro bowiem: „nie jest demokratycznym państwem prawnym państwo, które nie realizuje idei sprawiedliwości, przynajmniej pojmowanej jako dążenie do zachowania równowagi w stosunkach społecznych i powstrzymywanie się od kreowania nieusprawiedliwionych, niepopartych obiektywnymi wymogami i kryteriami przywilejów dla wybranych grup obywateli" (P. Tuleja, Komentarz do art. 2 [w:] Konstytucja RP. Komentarz, t. I, Art. 1-86, red. M. Safjan, L. Bosek, Warszawa 2016, nb. 85), to państwem takim nie będzie również państwo, które tworzy w procedurze karnej mechanizmy pozwalające na uniknięcie przez sprawcę przestępstwa sprawiedliwej kary z powodów formalnych. Przyjmowanie tego typu rozwiązań godzi w zasadę sprawiedliwości. Doktryna owoców zatrutego drzewa prowadzi bowiem do „skrajnych wypaczeń w funkcjonowaniu wymiaru sprawiedliwości, godzi w zasadę prawdy materialnej [...] oraz [...] prawa innych [niż oskarżony - dopisek A.P.] uczestników postępowania, w szczególności oskarżyciela posiłkowego (pokrzywdzonego)" (stanowisko Prokuratora Generalnego, s. 112-113). Z tych względów art. 168a k.p.k. jest zgody z art. 2 Konstytucji, choć przypomnieć należy, że: „[w] razie zakwestionowania zgodności aktu normatywnego ze standardami demokratycznego państwa prawnego, skonkretyzowanymi i rozwiniętymi w odrębnych postanowieniach ustawy zasadniczej, podstawę kontroli konstytucyjności powinny stanowić przede wszystkim szczegółowe przepisy konstytucyjne. $\mathrm{W}$ takich sytuacjach nie ma natomiast potrzeby powoływania - jako podstawy kontroli - zasady demokratycznego państwa prawnego, wyrażonej w art. 2 Konstytucji. Zasada ta pełni wówczas przede wszystkim funkcję wskazówki dla interpretacji wymienionych, szczegółowych przepisów ustawy zasadniczej” (wyrok TK z 9 czerwca 1998 r., sygn. akt K 28/97; zob. także wyrok TK z 9 października 2012 r., sygn. akt P 27/11).

3. Rzecznik postawił zarzut naruszenia przez art. 168a k.p.k. art. 42 Konstytucji, nie spełnił jednak wymogu formalnego obejmującego przedstawienie argumentów uzasadniających zarzut niezgodności przedmiotu kontroli ze wskazanym wzorcem kontroli. Dlatego w tym zakresie postępowanie na podstawie art. 59 ust. 1 pkt 2 u.o.t.p.TK podlega umorzeniu wobec niedopuszczalności wydania orzeczenia. Sejm pragnie w związku z tym zauważyć jedynie, że na prawo do obrony składają się: prawo do wyboru sposobu obrony, prawo do znajomości stawianych zarzutów, prawo do odpowiedniego czasu i możliwości przygotowania obrony, prawo do obrony osobistej, prawo do posiadania i korzystania z pomocy obrońcy, prawo do swobody wypowiedzi, prawo do dostępu do materiału dowodowego, prawo do inicjatywy dowodowej, prawo do udziału w czynnościach procesowych, prawo do zaskarżania decyzji procesowych i czynności orga- 
nów procesowych (T. Sroka, Komentarz do art. 42 [w:] Konstytucja RP. Komentarz, t. I, Art. 1-86, red. M. Safjan, L. Bosek, Warszawa 2016). Kwestionowany przez Rzecznika przepis nie uniemożliwia przedstawiania dowodów na swoją korzyść oraz kwestionowania dowodów świadczących przeciw niemu. Treść art. 168a k.p.k. nie podważa uprawnienia kwestionowania uzyskanych dowodów ani podważania ich wiarygodności. Zagwarantowanego w Konstytucji prawa do obrony nie można utożsamiać z prawem do uniknięcia odpowiedzialności przez sprawcę przestępstwa.

4. Sejm nie podziela także stanowiska Rzecznika, że art. 168a k.p.k. kwestionuje domniemanie praworządności działania organów państwa pro futuro. Istnieje bowiem fundamentalna różnica między wyrażeniem akceptacji dla naruszania prawa przez funkcjonariuszy - ze wszystkimi tego konsekwencjami a dostrzeżeniem, że naruszenia w praktyce się zdarzają i niesprawiedliwe jest obarczanie ich skutkami pokrzywdzonego. Tymczasem ma to miejsce w przypadku apriorycznego uniemożliwiania oceny uzyskanego w ten sposób materiału dowodowego przez sąd. Przepis ten nie powoduje wyłączenia odpowiedzialności osób winnych takich naruszeń. Tworzy jednak gwarancję, że orzeczenie sądu będzie wydane na podstawie całości ujawnionych $\mathrm{w}$ toku postępowania dowodowego okoliczności. Znajduje to oparcie w orzecznictwie TK, w którym podkreślono, że: „zasada art. 7 Konstytucji nie rodzi wprawdzie po stronie jednostek jej podlegających prawa podmiotowego «do władzy publicznej działającej tylko zgodnie z prawem (byłoby to nierealne, ponieważ musi istnieć zawsze margines ryzyka błędów, pomyłek)». Jednakże pojawienie się w Konstytucji art. 77 ust. 1 wprowadziło gwarancję, że ekonomiczny skutek tych ryzyk, błędów czy pomyłek nie będzie obciążał poszkodowanego" (wyrok TK z 23 września 2003 r., sygn. akt K 20/02). Ponownie trzeba podkreślić, że art. 168a k.p.k.: „nie nakazuje, nie umożliwia ani nie ułatwia organom władzy publicznej zachowania sprzecznego z prawem, w szczególności nie obejmuje zakresem unormowania zalegalizowania czynności nielegalnych. Przepis ten nie upoważnia w żadnej mierze organów państwa do działania poza prawem ani nie uwalnia funkcjonariuszy organów państwa od odpowiedzialności dyscyplinarnej, karnej i cywilnej związanej z niedopełnieniem obowiązków bądź przekroczeniem uprawnień. Innymi słowy, norma zawarta w tym przepisie nie ma wpływu na stwierdzenie naruszenia przez funkcjonariusza publicznego procedury postępowania, dokonania czynu zabronionego czy na uchylenie odpowiedzialności odszkodowawczej Państwa dochodzonej na gruncie art. 77 ust. 1 Konstytucji. Podkreślić należy, że naruszenie reguł postępowania przez funkcjonariuszy organów ścigania, jak również popełnienie czynu zabronionego, nadal podlega odpowiednim sankcjom w postępowaniu dyscyplinarnym, karnym i cywilnym. Przepis art. 168a k.p.k. stanowi jedynie, że orzekający sąd karny nie może pozostawić materiału dowodowego uzyskanego wskutek naruszenia przepisów postępowania przez funkcjonariuszy publicznych poza zakresem swojej oceny" (stanowisko Proku- 
ratora Generalnego, s. 119). Z tego względu art. 168a k.p.k. jest zgodny z art. 7 Konstytucji.

5. W ocenie Sejmu art. 168a k.p.k. nie pozostaje w koniecznym merytorycznym związku z art. 40 Konstytucji w związku art. 3 EKPC i dlatego nie stanowią one adekwatnych wzorców kontroli. Sejm pragnie podkreślić, że art. 168a k.p.k. w żaden sposób nie reguluje materii objętej treścią art. 40 Konstytucji w związku z art. 3 EKPC, w szczególności nie podważa doniosłości norm prawnych zawartych w tych przepisach. Z art. 168a k.p.k. nie można - co zostało już uprzednio wykazane - wywieść normy prawnej, która dopuszczałaby w jakiejkolwiek formie stosowanie tortur, okrutnego, nieludzkiego lub poniżającego traktowania i karania. Z tego względu należy uznać, że art. 168a k.p.k. nie jest niezgodny $\mathrm{z}$ art. 40 Konstytucji w związku z art. 3 EKPC.

6. Co do art. 45 ust. 1 Konstytucji i art. 6 EKPC wniosek Rzecznika dotyczy zasady sprawiedliwości (rzetelności) proceduralnej. Istota sprawiedliwości (rzetelności) proceduralnej zawiera się w zapewnieniu stronom możliwości korzystania z praw i gwarancji procesowych oraz zagwarantowaniu rzetelnego i merytorycznego rozpatrzenia sprawy. Ze względu na zbieżny zakres treściowy konstytucyjnej i konwencyjnej zasady sprawiedliwości (rzetelności proceduralnej), nie zachodzi potrzeba odrębnego rozważania zarzutu niezgodności kwestionowanej regulacji z art. 6 EKPC. Sprawiedliwość proceduralna należy do istoty konstytucyjnego prawa do sądu, albowiem prawo do sądu bez zachowania standardu rzetelności postępowania byłoby prawem fasadowym (wyroki TK z: 21 lipca 2009 r., sygn. akt K 7/09; 14 stycznia 2014 r., sygn. akt SK 25/11). Trybunał Konstytucyjny wyjaśnił, że istota sprawiedliwości proceduralnej zawiera się w stworzeniu stronom możliwości korzystania z praw i gwarancji procesowych oraz zapewnieniu rzetelnego i merytorycznego rozpatrzenia sprawy, które determinują takie elementy, jak: prawo strony do bycia wysłuchanym, prawo do informowania, przewidywalność rozstrzygnięć, sprawne rozstrzygnięcie sprawy w rozsądnym terminie, umożliwienie wszechstronnego zbadania okoliczności sprawy przez sąd. Zasada sprawiedliwości proceduralnej ma przy tym charakter uniwersalny, gdyż dotyczy wszystkich etapów i rodzajów postępowań, ale powinna być stosowana $\mathrm{z}$ uwzględnieniem funkcji i charakteru prawnego danej procedury (zob. wyroki TK z: 31 stycznia 2005 r., sygn. akt SK 27/03; 14 czerwca 2006 r., sygn. akt 53/05; 30 maja 2007 r., sygn. akt SK 68/06; 26 lutego 2008 r., sygn. akt SK 89/06; 9 lutego 2010 r., sygn. akt SK 10/09; 12 lipca 2011 r., sygn. akt SK 49/08). Dlatego też: „[s]prawiedliwość proceduralna nie może być oceniana w kategoriach abstrakcyjnych, niezależnie od kategorii spraw, które są przedmiotem rozpoznania sądowego, konfiguracji podmiotowych, znaczenia poszczególnych kategorii praw dla ochrony interesów jednostki itd. Ustawodawca zachowuje w tym zakresie dość znaczne pole swobody, które umożliwia kształtowanie procedur sądowych z uwzględnieniem tych zróżnicowanych czynników i zarazem w sposób stanowiący próbę wyważenia interesów pozostających w pewnym 
konflikcie" (wyrok TK z 1 lipca 2008 r., sygn. akt SK 40/07). Zasada sprawiedliwości proceduralnej nie ma bowiem charakteru absolutnego, gdyż jej realizacja może być ograniczana przez inne wartości, jeśli ograniczenia te spełniają przesłanki określone w art. 31 ust. 3 Konstytucji i nie naruszają istoty prawa do sądu (zob. wyroki TK z: 28 lipca 2004 r., sygn. akt P 2/04; 14 czerwca 2006 r., sygn. akt K 53/05; 20 maja 2008 r., sygn. akt P 18/07; 12 lipca 2011 r., sygn. akt SK 49/08). Wymogi związane ze sprawiedliwością proceduralną wymagają dostosowania kryteriów oceny rzetelności badanej procedury do jej funkcji i charakteru prawnego (wyroki TK z: 14 marca 2006 r., sygn. akt SK 4/05; 3 lipca 2007 r., sygn. akt SK 1/06; 12 lipca 2011 r., sygn. akt SK 49/08).

Do obecnych w orzecznictwie TK elementów składowych zasady sprawiedliwości proceduralnej w doktrynie dodaje się: „konieczność zapewnienia równości broni (P. Grzegorczyk, K. Weitz, Komentarz do art. 45 [w:] Konstytucja RP. Komentarz, t. I, Art. 1-86, M. Safjan, L. Bosek, 2017, Legalis). Jak podnoszą ci autorzy, «[w] związku z prawem do wysłuchania pozostaje prawo do dowodu (Recht auf Beweis), które obejmuje zespół uprawnień stron i uczestników oraz reguł wiążących sąd w kontekście postępowania dowodowego. [...] Podstawowe znaczenie ma tu prawo do tego, aby przedmiotem dowodu uczynić każdą sporną okoliczność, relewantną dla rozstrzygnięcia sprawy. Ponadto w tym kontekście należy rozpatrywać problematykę obecności stron i uczestników postępowania, w szczególności oskarżonego, w czasie przeprowadzania dowodów, prawo do zadawania pytań świadkom i biegłym, problematykę dopuszczalności dowodów nielegalnych, uwzględniania przytoczeń stron $\mathrm{w}$ ramach oceny dowodów, jak również ich prawa do roztrząsania wyników postępowania dowodowego, ograniczeń co do powinności składania zeznań w charakterze świadka (prawo do odmowy zeznań) i prezentacji dowodu w sądzie» (ibidem)" (stanowisko Prokuratora Generalnego, s. 83).

W orzecznictwie ETPC dostrzega się potrzebę ochrony prawa innych poza oskarżonym uczestników procesu karnego, co: „może [...] czasem wymagać pewnej restryktywności w wykładni art. 6, w szczególności wówczas, gdy prawa oskarżonego $\mathrm{w}$ procesie karnym pozostają $\mathrm{w}$ konflikcie $\mathrm{z}$ gwarancjami ofiary przestępstwa (zob. wyr. ETPCz 26.3.1985 r. w sprawie X. i Y. p. Niderlandom, par. 63 i nast.)" (P. Hofmański, A. Wróbel Komentarz do art. 6, op. cit.). ETPC: „podkreślał wielokrotnie w swoim orzecznictwie, że zagadnienie oceny dowodów w konkretnych sprawach leży poza zakresem jego kognicji i należy bez reszty do kompetencji organów krajowych. [...] Także zagadnienie dopuszczalności poszczególnych dowodów pozostawione jest wyłącznie sądom krajowym, albowiem Konwencja nie zawiera katalogu dopuszczalnych środków dowodowych, czy metod dowodzenia. Co więcej, nawet uzyskanie (i wykorzystanie) dowodu uzyskanego $\mathrm{z}$ naruszeniem tych standardów nie prowadzi automatycznie do stwierdzenia, że wyrok skazujący narusza art. 6 ust. 1. Innymi słowy, orzecznictwo strasburskie nigdy nie było skłonne do prostego przejęcia amerykań- 
skiej doktryny "owoców zatrutego drzewa»" (ibidem). Stąd nieuprawniony jest pogląd Rzecznika, iż EKPC oraz powstałe na jej gruncie orzecznictwo ETPC przesądza o potrzebie przyjęcia w procesie karnym doktryny owoców zatrutego drzewa. Wręcz przeciwnie w orzecznictwie ETPC powstała „doktryna pozytywnych zobowiązań" (positive obligations) państw, które ratyfikowały ETPC, która wyraża nakaz ochrony praw pokrzywdzonych i świadków (stanowisko Prokuratora Generalnego, s. 85-87). W ocenie Sejmu trudno znaleźć bardziej drastyczny sposób pogwałcenia praw pokrzywdzonego, jak odmówienie ukarania sprawcy przestępstwa mimo istnienia dowodów świadczących o jego winie.

Powoduje to, że nie można podzielić oceny Rzecznika co do niezgodności art. 168a k.p.k. z art. 45 ust. 1 Konstytucji w związku z art. 6 EKPC. Po pierwsze: „oparcie wyroku na wadliwie uzyskanym materiale dowodowym nie może być uznane samo w sobie za naruszające uprawnienie oskarżonego do rzetelnego procesu, co potwierdza dominująca linia orzecznicza sądów powszechnych oraz Sądu Najwyższego, jednoznacznie odrzucająca doktrynę «owoców zatrutego drzewa» (por. m.in. wyroki: Sądu Apelacyjnego w Katowicach - z dn. 27 maja 2004, sygn. II AKa 160/04, LEX nr 149706; Sądu Najwyższego - z dn. 14 listopada 2006 r., sygn. V KK 52/06, LEX nr 202271; z dn. 22 lutego 2007 r., sygn. V KK 183/06, LEX nr 274709; z dn. 5 lutego 2008 r., sygn. SNO 2/08, LEX nr 432189; z dn. 3 grudnia 2008 r., sygn. V KK 195/08, LEX nr 482213 oraz z dn. 25 marca 2010 r., sygn. I KZP 2/10, LEX nr 564518; Sądu Apelacyjnego w Lublinie - z dn. 22 stycznia 2013 r., sygn. II AKa 301/12, LEX nr 1289474; Sądu Najwyższego - z dn. 30 października 2013 r., sygn. II KK 139/13, LEX nr 1391587, i z dn. 2 lutego 2016 r., sygn. IV KK 346/15, LEX nr 1976252). Wbrew bowiem stanowisku Wnioskodawcy, jak trafnie wskazał Sąd Najwyższy w wyroku z dnia 2 lutego 2016 r., sygn. IV KK 346/15, «nie budzi wątpliwości, że w polskiej procedurze karnej nie obowiązuje reguła zakazu wykorzystywania w procesie 'owoców zatrutego drzewa'» (LEX 2017)" (ibidem, s. 87-88).

Nie można zasadnie twierdzić, że art. 168a k.p.k. ogranicza którekolwiek z uprawnień stron składających się na zasadę sprawiedliwości (rzetelności) proceduralnej. Inaczej niż przyjmuje Rzecznik, art. 168a k.p.k. nie oznacza nakazu wydania wyroku na podstawie dowodów uzyskanych z uchybieniem wymogom formalnym. Przepis ten nakazuje jedynie poddać taki dowód ocenie sądu, która odbywa się z wykorzystaniem wszystkich reguł oceny dowodów. W tym zakresie art. 168a k.p.k. pozwala na realizację zasady prawdy materialnej, która także jest jednym z elementów zasady sprawiedliwości proceduralnej wynikającej z art. 45 ust. 1 Konstytucji (J. Grajewski, S. Steinborn, Zasada prawdy materialnej jako granica upraszczania procesu karnego [w:] Zasada prawdy materialnej. Materiały z konferencji. Krasiczyn, 15-16 października 2005 r., red. Z. Sobolewski, G. Artymiak, Kraków 2006, s. 209; S. Waltoś, Naczelne zasady procesu karnego, Warszawa 1999, s. 18; J. Skorupka, Zasada prawdy materialnej w projekcie noweli Kodeksu postępowania karnego opracowanym przez Komisje Kodyfikacyjna Pra- 
wa Karnego [w:] P. Kardas, T. Sroka, W. Wróbel, Państwo prawa i prawo karne. Ksiega Jubileuszowa Profesora Andrzeja Zolla, t. II, Warszawa 2012, s. 1745-1746; B. Nita, A. Światłowski, Kontradyktoryjny proces karny (między prawda materialna a szybkością postępowania), „Państwo i Prawo” 2012, z. 1, s. 33-49). Zasada prawdy materialnej ma dwa aspekty - pragmatyczny i optymalizacyjny. W Konstytucji przyjmuje postać: „kierowanej do prawodawcy dyrektywy odpowiedniego ukształtowania modelu procesowego, a w szczególności postępowania dowodowego, tak by stwarzał największe z możliwych prawdopodobieństwo zgodności twierdzeń organu procesowego o pozajęzykowej rzeczywistości z tą rzeczywistością. Na poziomie stosowania prawa kierowany do organu procesowego nakaz takiego przeprowadzenia określonych w procedurze czynności dowodowych, by ich rezultaty w postaci twierdzenia dotyczącego zdarzenia faktycznego w największym stopniu były zgodne z rzeczywistym jego przebiegiem, a więc z pozajęzykową rzeczywistością, w tym sensie nawiązuje do korespondencyjnej teorii prawdy, wskazując, że celem postępowania dowodowego jest maksymalna wierność (adekwatność, zgodność) twierdzenia o zdarzeniu faktycznym z rzeczywistym przebiegiem tego zdarzenia w pozajęzykowej rzeczywistości” (P. Kardas, Zasada prawdy materialnej w perspektywie korespondencyjnej, koherencyjnej, pragmatycznej i konsensualnej teorii prawdy (kilka uwag na tle propozycji nowego ujęcia przepisów dotyczących postępowania dowodowego przed sądem pierwszej instancji oraz postępowania dowodowego w toku postępowania przygotowawczego) [w:] Kontradyktoryjność w polskim procesie karnym, red. P. Wiliński, 2013, LEX). Potrzeba poszanowania w procesie karnym zasady prawdy materialnej wynika także ze skutków, jakie niesie poddanie jedynie formalizmowi procesowemu rozstrzygnięcie, które może oznaczać uwolnienie sprawcy przestępstwa od odpowiedzialności, skazanie osoby niewinnej, a wreszcie poprzez niezgodny ze stanem faktycznym wyrok także naruszenie prawa osoby pokrzywdzonej przestępstwem do ukarania sprawcy jej krzywd.

Artykuł 168a k.p.k. nie narusza także zasady równości broni w postępowaniu sądowym, bowiem jedynie reguluje zakres materiału dowodowego, jaki powinien podlegać ocenie sądu, pozostawiając stronom procesu sądowego równe prawa $\mathrm{w}$ zakresie kwestionowania owego materiału. Zasada równości broni $\mathrm{w}$ procesie karnym nie może być utożsamiana $\mathrm{z}$ uprawnieniem do eliminowania rzeczywistych dowodów popełnienia przestępstwa przez oskarżonego z wyjątkiem dowodów naruszających obowiązujące zakazy dowodowe. Podobnie wynikająca z art. 45 ust. 1 Konstytucji zasada przewidywalności postępowania zgodnie $z$ orzecznictwem TK oznacza zapewnienie stronom i innym uczestnikom postępowania przewidywalności przebiegu postępowania sądowego przez odpowiednią spójność i logikę mechanizmów, którym podmioty te są poddawane $\mathrm{w}$ toku rozpoznawania ich sprawy (wyroki TK z: 31 marca 2005 r., sygn. akt SK 26/02; 2 października 2006 r., sygn. akt SK 34/06; 30 maja 2007 r., sygn. akt SK 68/06), a nie z możnością przewidywania korzystnego dla siebie 
rozstrzygnięcia sądowego. Zasada przewidywalności wymaga więc, by istniały jasne, z góry określone i mające zastosowanie w poszczególnych postępowaniach, reguły ich prowadzenia od początku aż do ich zakończenia (wyroki TK Z: 14 listopada 2007 r., sygn. akt SK 16/05; 29 kwietnia 2008 r., sygn. akt SK 11/07; 30 października 2012 r., sygn. akt SK 8/12). Stąd też w ocenie Sejmu nie można zgodzić się z poglądem Rzecznika, że przepis art. 168a k.p.k. narusza zasadę przewidywalności postępowania. Przeciwnie, obecne brzmienie art. 168a k.p.k. stanowi doprecyzowanie reguł postępowania dowodowego w postępowaniu karnym. Przesądza, że faktyczną podstawę rozstrzygnięcia w procesie karnym stanowią wszelkie okoliczności ujawnione w toku postępowania, z wyjątkami wynikającymi z zawartych w treści przepisów procesowych zakazów dowodowych. W obowiązującym uprzednio stanie prawnym niektóre dowody mogły być uwzględnione lub wyłączone zależnie od składu orzekającego. Obecne brzmienie art. 168a k.p.k. powinno powodować ukształtowanie się jednolitej linii orzeczniczej, co zwiększa przewidywalność postępowania. Z przytoczonych wyżej powodów art. 168a k.p.k. jest zgodny z art. 45 ust. 1 Konstytucji w związku z art. 6 EKPC.

7. Rzecznik postawił także zarzut niezgodności art. 168a k.p.k. z art. 47 oraz z art. 51 ust. 2, 3 i 4 Konstytucji. Przy czym w zakresie art. 51 ust. 2 Konstytucji Rzecznik nie wykazał, na czym miałoby polegać naruszenie tego przepisu przez art. 168a k.p.k. Podobnie, mimo wskazania jako wzorca kontroli art. 51 ust. 3 Konstytucji, Rzecznik nie uzasadnił swojego stanowiska. W tym zakresie w uzasadnieniu wniosku nie umieszczono ani tej jednostki redakcyjnej wprost, ani żadnego zdania, które mogłoby się odnosić bezpośrednio do tego wzorca kontroli. W związku z czym Sejm wnosi o umorzenie postępowania w zakresie art. 51 ust. 2 i 3 Konstytucji na podstawie art. 59 ust. 1 pkt 2 u.o.t.p.TK ze względu na niedopuszczalność wydania orzeczenia. Odnośnie do art. 47 i art. 54 ust. 1 Konstytucji odwołać się można do uwag poczynionych w pkt 1. Należy też zwrócić uwagę, że wykładnia tego przepisu zawarta we wniosku Rzecznika mogłaby prowadzić do wniosku, że jakiekolwiek, nawet nieznaczące, naruszenie przepisu ustawy w toku pozyskiwania materiału dowodowego (który można uznać za informację w rozumieniu tego przepisu) powinno prowadzić do niezwłocznego usunięcia i wykluczenia na żądanie oskarżonego tak uzyskanego materiału dowodowego z podstawy orzekania. Przyjęcie jednak takiej wykładni godziłoby w inne, gwarantowane przez ustawę zasadniczą, prawa i wolności, a także w stanowiącą podstawę ustroju Rzeczypospolitej Polskiej zasadę sprawiedliwości. Wymaga zastanowienia to, czy działalność przestępcza w ogóle korzysta z ochrony prywatności przewidzianej w art. 47 i art. 51 Konstytucji. M. Wild wskazuje, że: „można stwierdzić, że sferą życia prywatnego objęte są takie okoliczności, w stosunku do których można przyjąć prymat interesu jednostki nad interesem publicznym, domniemanie przewagi prawa jednostki do bycia pozostawioną samej sobie nad interesem publicznym bądź interesem innych podmiotów. [...] Należy 
zatem ustalić sytuacje, w których jednostce nie przysługuje roszczenie o poszanowanie tak rozumianej prywatności, oraz objąć pozostałe przypadki ochroną wyprowadzaną z art. 47 Konstytucji RP” (M. Wild, Komentarz do art. 47 [w:] Konstytucja RP. Komentarz, t. I, Art. 1-86, red. M. Safjan, L. Bosek, 2017, Legalis, teza 55-58). Uznać można, że działalność przestępcza jako naruszająca wolności i prawa innych osób, do których poszanowania każdy jest zobowiązany zgodnie $\mathrm{z}$ art. 31 ust. 2 Konstytucji, pozostaje poza obszarem konstytucyjnego prawa do prywatności. Jednostka, popełniając przestępstwo, wykracza bowiem poza sferę objętą swoim prawem do prywatności. Czyn zabroniony trudno bowiem objąć pojęciem „życia intymnego”, „życia rodzinnego” czy „̇̇ycia prywatnego”. Stąd też działalność przestępcza nie może być uznana za uprawnioną do korzystania z gwarancji przewidzianych w art. 47 i art. 51 ust. 4 Konstytucji. Z powyższych względów należy stwierdzić, że art. 168a k.p.k. jest zgodny z art. 47 oraz z art. 51 ust. 4 Konstytucji.

8. W ocenie Sejmu art. 168a k.p.k. jest zgodny z art. 31 ust. 3 Konstytucji. Po pierwsze, jest przydatny, bowiem umożliwia realizację celu założonego przez ustawodawcę, tj. uczynienie podstawą orzeczenia sądu karnego wszystkich okoliczności sprawy, w tym materiału dowodowego uzyskanego z naruszeniem przepisów postępowania lub za pomocą czynu zabronionego z wyjątkami wynikającymi z art. 168a k.p.k. Po drugie, jego wprowadzenie było „konieczne”, tj. niezbędne dla ochrony bezpieczeństwa państwa i porządku publicznego oraz wolności i praw innych osób, a więc wartości wymienionych w art. 31 ust. 3 Konstytucji. Konieczność taka powstała w związku z pojawieniem się w doktrynie oraz judykaturze tendencji do wprowadzania do polskiego procesu karnego doktryny owoców zatrutego drzewa. W związku z tym ustawodawca postanowił nie ograniczać się jedynie do uchylenia poprzedniego brzmienia art. 168a k.p.k. wprowadzonego w 2013 r., ale ustawą nowelizującą nadał mu nowe brzmienie, przełamujące tendencje, które zaczęły się pojawiać już wcześniej. W ten sposób ustawodawcy udało się zagwarantować pociągnięcie do odpowiedzialności karnej sprawcy przestępstwa oraz uwolnienie od tej odpowiedzialności osoby niewinnej w każdej sytuacji, w której istotny materiał dowodowy mógłby podlegać wykluczeniu wyłącznie z uwagi na wadliwość w procedurze jego uzyskania. Wreszcie, art. 168a k.p.k. spełnia wymóg proporcjonalności sensu stricto, tj. cel jego wprowadzenia i jego efekty pozostają w proporcji do nałożonych przez nią na obywatela (tu: podejrzanego/oskarżonego) ograniczeń. Przewidziany w art. 168a k.p.k. zakaz stosowania doktryny owoców zatrutego drzewa nie ogranicza bowiem prawa oskarżonego do obrony, uniemożliwia mu jedynie powoływanie się na uchybienia formalne w celu wyłączenia spod oceny sądu dowodów świadczących przeciw niemu. Jednocześnie jednak gwarantuje mu, że materiał dowodowy przesądzający o jego niewinności nie zostanie wyeliminowany z zakresu oceny sądu jedynie na gruncie formalnych uchybień w jego zdobyciu. Za pomocą kwestionowanego przez Rzecznika rozwiązania ustawodawca osiąga konstytucyjnie 
legitymowany cel. Spełniony jest więc test proporcjonalności. Z tego względu art. 168a k.p.k. jest zgodny z art. 31 ust. 3 Konstytucji.

9. Podsumowując, celem procesu karnego jest: „ochrona interesów państwa i los człowieka, którego czyny stanowią przedmiot badania w sprawie karnej, są uzależnione od tego czy została ustalona prawda w tejże sprawie czy też nie dało się jej ustalić. Rozstrzygane są tu bowiem kwestie winy albo niewinności osoby pociągniętej do odpowiedzialności karnej. Dlatego też problem prawdy w procesie karnym jest nierozerwalnie związany z problemem gwarancji, zapewniających zarówno jej wykrycie, jak i chroniących osobę pociągniętą do odpowiedzialności przed bezpodstawnym oddaniem pod sąd i skazaniem (M.S. Strogowicz, Prawda obiektywna i dowody sadowe $w$ radzieckim procesie karnym, Warszawa 1959, s. 21)" (M. Warchoł, Ciężar dowodu w procesie karnym. Studium prawnoporównawcze, Warszawa 2017, s. 289). Artykuł 168a k.p.k. stanowi gwarancję ustalenia w sprawie karnej faktycznego (prawdziwego) przebiegu zdarzenia, co zapewnia gwarancję prawa zarówno pokrzywdzonego, jak też oskarżonego, w tym w szczególności osoby niewinnej. Uwzględniając podstawowe wartości konstytucyjne, ustawodawca nie może zrezygnować w procesie karnym z poszukiwania prawdy na rzecz formalizmu, którego jedynym z wyrazów jest doktryna owoców zatrutego drzewa.

Mając na uwadze przedstawione argumenty, należy uznać, że art. 168a k.p.k. jest zgodny $\mathrm{z}$ art. 45 ust. $1 \mathrm{w}$ związku $\mathrm{z}$ art. 51 ust. $4 \mathrm{w}$ związku $\mathrm{z}$ art. 31 ust. 3 Konstytucji w związku z art. 6 EKPC, a także z art. 2, art. 7 i art. 47 Konstytucji oraz nie jest niezgody $z$ art. 40 Konstytucji w związku $z$ art. 3 EKPC.

Ponadto wnoszę o umorzenie postępowania w pozostałym zakresie na podstawie art. 59 ust. 1 pkt 2 u.o.t.p.TK, ze względu na niedopuszczalność wydania orzeczenia.

\section{Bibliografia}

Banaszak B., Konstytucja Rzeczypospolitej Polskiej. Komentarz, Warszawa 2012, komentarz do art. 51.

Banaszak B., Konstytucja Rzeczypospolitej Polskiej. Komentarz, Warszawa 2009, komentarz do art. 40.

Conti C., L'imputato nel procedimento connesso. Diritto al silenzio e obbligo di verità, Cedam 2003.

Cordopatri F., L'abuso del processo. Diritto positivo, Padova 2000.

Garlicki L., Komentarz do art. 3 [w:] Konwencja o ochronie praw człowieka i podstawowych wolności, t. I, Komentarz do artykułów 1-18, red. L. Garlicki, Warszawa 2010.

Garlicki L., Komentarz do art. 31 [w:] Konstytucja Rzeczypospolitej Polskiej. Komentarz, t. III, red. L. Garlicki, Warszawa 2003.

Grabenwarter Ch., Europäische Menschenrechtskonvention, München-Basel-Wien 2008. 
Grajewski J., Steinborn S., Zasada prawdy materialnej jako granica upraszczania procesu karnego [w:] Zasada prawdy materialnej. Materiały z konferencji. Krasiczyn, 1516 października 2005 r., red. Z. Sobolewski, G. Artymiak, Kraków 2006.

Grzegorczyk P., Weitz K., Komentarz do art. 45 [w:] Konstytucja RP. Komentarz, t. I, Art. 1-86, red. M. Safjan, L. Bosek, 2017, Legalis.

Hofmański P., Wróbel A., Komentarz do art. 6 [w:] Konwencja o ochronie praw człowieka i podstawowych wolności, t. I, Komentarz do artykułów 1-18, red. L. Garlicki, Warszawa 2010.

Human Rights Practice, Londyn 2006, Article 6 Right to a Fair Trial, M. Purchase, E. Schutzer-Weismann.

Jamróz L. , Skarga konstytucyjna. Wstępne rozpoznanie, Białystok 2011.

Kardas P., Zasada prawdy materialnej w perspektywie korespondencyjnej, koherencyjnej, pragmatycznej $i$ konsensualnej teorii prawdy (kilka uwag na tle propozycji nowego ujecia przepisów dotyczących postępowania dowodowego przed sądem pierwszej instancji oraz postępowania dowodowego $w$ toku postępowania przygotowawczego) [w:] Kontradyktoryjność $w$ polskim procesie karnym, red. P. Wiliński, 2013, LEX.

Karlik P., Sroka T., Wiliński P., Komentarz do art. 42 [w:] Konstytucja RP. Komentarz, t. I, Art. 1-86, red. M. Safjan, L. Bosek, Warszawa 2016.

Kopff A. , Koncepcje prawa do intymności i do prywatności życia. Zagadnienia konstrukcyjne, „Studia Cywilistyczne” 1972, t. XX.

Królikowski M., Szczucki K., Komentarz do art. 40 [w:] Konstytucja RP. Komentarz, t. I, Art. 1-86, red. M. Safjan, L. Bosek, Warszawa 2016.

Lipowicz I., Komentarz do art. 51 [w:] Konstytucje Rzeczypospolitej oraz komentarz do Konstytucji RP z 1997 roku, red. J. Boć, Wrocław 1998.

Morawska E., Klauzula państwa prawnego w Konstytucji RP na tle orzecznictwa TrybunaŁu Konstytucyjnego, Toruń 2003.

Nita B., Światłowski A., Kontradyktoryjny proces karny (między prawda materialna a szybkościa postępowania), „Państwo i Prawo” 2012, z. 1.

Osborn D., Suppressing the Truth: Judicial Exclusion of Illegally Obtained Evidence in the United States, Canada, England and Australia, Murdoch University Electronic Journal of Law, http://www.austlii.edu.au/au/joumals/MurUEJL/2000/44.html.

Sarnecki P., Komentarz do art. 40 [w:] Konstytucja Rzeczypospolitej Polskiej. Komentarz, t. III, red. L. Garlicki, Warszawa 2003.

Sarnecki P., Komentarz do art. 42 [w:] Konstytucja Rzeczypospolitej Polskiej. Komentarz, t. III, red. L. Garlicki, Warszawa 2003.

Sarnecki P., Komentarz do art. 47 [w:] Konstytucja Rzeczypospolitej Polskiej. Komentarz, t. III, red. L. Garlicki, Warszawa 2003.

Skorupka J., Udostępnienie akt sprawy podejrzanemu, „Prokuratura i Prawo” 2007, nr 5. Skorupka J., Zasada prawdy materialnej w projekcie noweli Kodeksu postępowania karnego opracowanym przez Komisje Kodyfikacyjna Prawa Karnego [w:] P. Kardas, Sroka T., Wróbel W., Państwo prawa i prawo karne. Księa Jubileuszowa Profesora Andrzeja Zolla, t. II, Warszawa 2012. 
Sobczak J., Komentarz do art. 4 [w:] Karta praw podstawowych Unii Europejskiej. Komentarz, red. A. Wróbel, Warszawa 2013.

Sokolewicz W., Prawo do prywatności [w:] Prawa człowieka w Stanach Zjednoczonych, Warszawa 1985.

Sokolewicz W., Komentarz do art. 7 [w:] Konstytucja Rzeczypospolitej Polskiej. Komentarz, t. V, red. L. Garlicki, Warszawa 2007.

Sroka T., Komentarz do art. 42 [w:] Konstytucja RP. Komentarz, t. I, Art. 1-86, red. M. Safjan, L. Bosek, Warszawa 2016.

Strogowicz M.S., Prawda obiektywna i dowody sadowe $w$ radzieckim procesie karnym, Warszawa 1959.

Tuleja P., Komentarz do art. 2 [w:] Konstytucja RP. Komentarz, t. I, Art. 1-86, red. M. Safjan, L. Bosek, Warszawa 2016.

W. Sokolewicz, M. Zubik, Komentarz do art. 2 [w:] Konstytucja Rzeczypospolitej Polskiej. Komentarz, t. I, red. L. Garlicki, M. Zubik, Warszawa 2016.

Waltoś S., Naczelne zasady procesu karnego, Warszawa 1999.

Warchoł M., Ciężar dowodu w procesie karnym. Studium prawnoporównawcze, Warszawa 2017.

Warchoł M., Pojęcie „nadużycia prawa” w prawie procesowym, „Prokuratura i Prawo” 2007, nr 11.

Weber U., Der Mißbrauchprozessualer Rechte im Strafverfahren, GA 1975.

Wild M., Komentarz do art. 47 [w:] Konstytucja RP. Komentarz, t. I, Art. 1-86, red. M. Safjan, L. Bosek, 2017, Legalis.

Winczorek P. , Komentarz do Konstytucji Rzeczypospolitej Polskiej z dnia 2 kwietnia 1997 roku, Warszawa 2008.

Wojtyczek K., Ciężar dowodu i argumentacji w procedurze kontroli norm przez Trybunat Konstytucyjny, „Przegląd Sejmowy” 2004, nr 1.

Wojtyczek K., Granice ingerencji ustawodawczej w sferę praw człowieka w Konstytucji RP, Kraków 1999.

Zakolska J., Zasada proporcjonalności w orzecznictwie Trybunału Konstytucyjnego, Warszawa 2008. 